\title{
ÉPÍTÉSZETTÖRTÉNET ÉS ÉPÍTÉSZETI TERVEZÉS
}

\author{
AZ ÉPÍTÉSZOKTATÁS MEGƯJULÁSÁNAK KÉRDÉSEI \\ AZ 1930-AS NEMZETKÖZI ÉPÍTÉSZKONGRESSZUS \\ MÜEGYETEMI KIÁLLÍTÁSA KAPCSÁN
}

\author{
FEHÉR KRISZTINA* - KRÄHLING JÁNOS** \\ *egyetemi tanársegéd. BME Építészettörténeti és Múemléki Tanszék, 1111 Budapest, \\ Mủegyetem rkp. 3. K II. 82. Tel.: (+36-1) 463-1330. E-mail: feher.krisztina@eptort.bme.hu \\ **Dr. habil. tanszékvezető egyetemi tanár. BME Építészettörténeti és Múemléki Tanszék, \\ 1111 Budapest, Müegyetem rkp. 3. K II. 82. Tel.: (+36-1) 463-1330. E-mail: krahling@eptort.bme.hu
}

\begin{abstract}
A két világháború közötti magyar építészeti közélet egyik legnagyobb hatású eseménye az 1930-ban Budapesten rendezett XII. Nemzetközi Építészkongresszus volt. A kongresszus programjához kapcsolódóan a Mücsarnokban nemzetközi tervkiállítást, a Mủegyetemen pedig hallgatói tervekből készült kiállítást rendeztek. Ez utóbbinak érthető módon eltörpül a sajtóbeli visszhangja a másikhoz képest, az Építészettörténeti és Müemléki Tanszék rajztárának feldolgozásakor azonban egy olyan összefüggő tablósorozat került elö, amelynek egységes, öt nyelven feliratozott grafikája és keltezései is arra utalnak, hogy a Múegyetem kiállítási anyagához tartozhatott. A tablókra kasírozott építészettörténeti rajzok bizonyíthatják, és ekképpen majdhogynem az egyedüli bizonyítékai, hogy a Mủegyetemen a tervezésoktatás mellett más tárgycsoportok, így az építészettörténet is bemutatásra került. A tablók fontos adalékot szolgáltatnak az építészettörténet oktatásának két világháború közötti változásairól, a kongresszus és a kiállítások sajtóba leszűrődött visszhangja pedig a 19. században még egységben lévő építészeti tervezés és építészettörténet tovább élő viszonyára utalnak.
\end{abstract}

Kulcsszavak: 1930, építészkongresszus, Mủegyetem, építészettörténet

\section{BEVEZETÖ}

Az építészettörténet oktatása és a kortárs építészeti tervezés eltávolodása csaknem egy évszázadra tekint vissza. A 19. században a múlt építészete lényegében a jelen építészete is volt. Habár gyakran stílusban tervezésként beszélünk róla, a középkort historizáló építészek sokszor a szerkezeti részletekbe menően ismerték és alkalmazták a régi megoldásokat, amely mögött a stílusjegyeken messze túlmutató, mélyebb tudás állt. A századfordulón megjelenő új technológiák és anyagok ellentmondást generáltak az acél és üveg nyújtotta lehetőségek és a hagyományos formák között, amelyre a modern építészet eszméjének kiáltványszerü elterjedése volt a válasz. Az ellentmondás kevésbé forradalmi feloldására azonban emellett más törekvések is születtek (magyar stíluskeresés, art deco, szecesszió stb.), amelyek nem a múlttól való szigorú elzárkózásban, hanem abból merítve keresték a megoldást. 
Az ezen irányzatok által meghatározott magyar építészet világháború utáni helyzetképét jól jellemzik az 1930-ban Budapesten rendezett Nemzetközi Építészkongresszus előkészítő munkálatairól, lebonyolításáról és utóhatásáról tudósító újságcikkek és kiadványok. A kongresszus kapcsán a müegyetemi oktatás is szélesebb közönség figyelmére tarthatott számot. A szakma képviselői elvárásként fogalmazták meg, hogy az építészek képzése tartson lépést az új irányzatokkal és technikákkal. ${ }^{1}$ E célnak megfelelően a tanrend gyakori megreformálásának eredményeképpen az építészeti tudás egyre inkább szakági részekre oszlott, mivel már külön tantárgyakon kellett oktatni az épületszerkezeti, gépészeti, gazdasági, jogi ismereteket. Az építészettörténet oktatása is egy lett a segéddiszciplínák sorában, de mivel a többi tantárgycsoporthoz képest ezt nem az új igények hívták életre, létjogosultsága időről időre megkérdőjeleződik.

Az 1930-as XII. Nemzetközi Építészkongresszus keretében nemzetközi tervkiállítást is rendeztek, amivel párhuzamosan Kotsis Iván a Müegyetemen is rendezett kiállítást a hallgatók terveiből. A BME Építészettörténeti és Mủemléki Tanszékének 2014-ben életre hívott Rajz és Fotótárából (továbbiakban Építészettörténeti Rajztár) egy olyan tablósorozat került elő, amelynek keltezése és egységes, öt nyelven feliratozott formátuma arra utal, hogy a müegyetemi kiállításon szerepelhetett.

A tablók témája azonban korántsem a modern szellemiségében készült, hanem a középkori építészettörténeti tantárgycsoport kitűnő hallgatói rajzait tartalmazza. Ez a 22 rajz talán az egyetlen tanúja annak, hogy Kotsis a külföldi szakmai közönség számára a Mủegyetemen nemcsak a tervezési tantárgyakat, hanem más tárgycsoportok munkáit is bemutatta, pedig a korabeli sajtóban ennek nyomát alig lehet megtalálni.

\section{NEMZETKÖZI ÉPÍTÉSZKONGRESSZUS, 1930, BUDAPEST}

A Mủegyetem és az ott megrendezett hallgatói kiállítás azért volt fontos helyszíne az 1930. szeptember 6-tól 13-ig tartó programsorozatnak, mert a kongresszus vitatémái közül az első a korszerü építészoktatás aktuális kérdéseit vitatta meg. Az előkészületek már 1929-ben megkezdődtek, aminek keretében a szakma szélesebb köre számára Bierbauer (Borbiró) Virgil buzdító írása adta tudtul a kongresszus napirendi pontjait és a kapcsolódó építészeti tervkiállítás hírét. ${ }^{2}$ A szervezési munkálatokra a C. P. I. A. (Comité Permanent Internationale des Architectes) felkérte magyar szakosztályát, melynek elnöke Kertész K. Róbert, ügyvezető elnöke K. Virágh Andor, fötitkára Rerrich Béla volt. A tagokhoz, Medgyaszay Istvánhoz, Jakabffy Zoltánhoz és Bierbauer Virgilhez ${ }^{3}$ a kongresszusra való tekintettel abban az évben még négyen

\footnotetext{
${ }^{1}$ Komor 1929.

${ }^{2}$ Bierbauer 1929.

${ }^{3}$ Bierbauer 1929. 370.
} 
csatlakoztak: Hoepfner Guido, Sándy Gyula, Schulek János és Wälder Gyula. ${ }^{4}$ A Múcsarnokba és a Nemzeti Szalonba tervezett professzionális tervkiállítás megrendezésére külön kiállítási albizottságot hoztak létre Wälder vezetésével. ${ }^{5}$

A kongresszus öt napirendi pontja: 1. az építészeti szakoktatás reformja, 2. az építészeti kamarák, érdektársulások helyzete, 3. az építészek szerzői jogai, 4. az építész szerepe az ipari építkezéseknél és 5. a nagy termek akusztikája volt. ${ }^{6}$

Az első számú téma az építészképzés aktuális kérdéseiről lényegében nem hozott új eredményeket, mivel Kotsis Iván szerint - aki a szekció szervezésében is részt vett - az összes lényeges ponton végrehajtottak már reformokat a Müegyetemen. ${ }^{7}$

Az 1930-as aktuális tanrend valóban tükrözte már, hogy az építésznek már nemcsak a tervezéshez kellett értenie müvészi fokon, hanem meg kellett tanulnia a statikai, kivitelezési, szerkezettani, anyagi, jogi, közigazgatási és adminisztratív ismereteket is. ${ }^{8}$ A kongresszusi szekción tehát lényegében nem hangzott el újdonság, Kotsis szerint azonban nem is ez volt a programsorozat legfontosabb hozadéka, hanem a magyar építészek kapcsolatteremtése a külföldi kollégákkal. ${ }^{9}$ A kongresszusnak a szervezők szerint is az ismerkedés, szakmai kapcsolatok kiépítése volt a leglényegesebb célja, amit tudatosan elö is segítettek a hivatalos program beosztásával: bőséges időt szenteltek az ebédszünetekre, kirándulásokra, ahol a szakmai kapcsolatok, barátságok, eszmecserék, beszélgetések kialakulhattak. ${ }^{10}$

A XII. építészkongresszusnak több hivatalos kiadványa készült öt idegen nyelven (magyar, angol, német, francia, olasz). A résztvevök köszöntésére a Tér és Forma 1930. szeptemberi száma a magyar korszerü építészet remekeit mutatta be 100 képpel, a mücsarnoki tervkiállítás anyagából kölcsönözve. A kongresszus építészeti tervkiállításának és a nemzetközi jelentőségü eszmecseréknek a sikerén felbuzdulva az Építészek Állandó Bizottsága (C. P. I. A.) nemzetközi építészeti szakfolyóirat indítása mellett döntött, amelynek szerkesztőségéhez 17 ország képviselői csatlakoztak. A nyitószám gyanánt 1931-ben a Tér és Forma negyedik évfolyamának hetedik száma Revue International d'Architecture címmel nemzetközi kiadványként jelent meg. ${ }^{11}$

${ }^{4}$ K. Virágh 1929. 157.

${ }^{5}$ Az Est 1929. (november 3.) 9. A szervezőbizottság albizottságai voltak: végrehajtóbizottság, intézőbizottság, propagandabizottság, kiállítási bizottság, tárgyalások bizottsága, kirándulási bizottság, női bizottság. A végrehajtóbizottságból alakult meg az elnöki bizottság: Kertész K. Róbert, K. Virágh Andor, Wälder Gyula, Hoepfner Guidó, Sándy Gyula, Nagy K. Császár Ferenc, Rerrich Béla, Fritz Oszkár, dr. Bierbauer Virgil, Orth Ambrus, Nászay Miklós, Zilahy Dezső. Rerrich 1930. 10.

${ }^{6}$ Kiss 1930; K. Virágh 1929. 157; Bierbauer 1929. 371.

${ }^{7}$ Prakfalvi 2010. 199.

${ }^{8}$ Kotsis 1930 b.

${ }^{9}$ Prakfalvi 2010. 199.

${ }^{10}$ Építö Ipar - Épitő Müvészet 54 (1930) 119-120 (augusztus 1.)

${ }^{11}$ Tér és Forma 4 (1931) 7. (július) 


\section{AZ 1930-AS XII. NEMZETKÖZI ÉPÍTÉSZKONGRESSZUS KIÁLLÍTÁSAI}

A Mücsarnokban rendezett nemzetközi tervkiállítás természetesen a kongresszus fő attrakciója volt. Ennek megfelelően a sajtóvisszhangja is nagy volt, ${ }^{12}$ bár a programsorozat lezárultával a Nemzeti Szalonban lévő magyaros stíluskövetők csoportjáról is számos cikk született. A Müegyetemen rendezett hallgatói kiállítás érthető módon nem állt kifejezetten az érdeklődés középpontjában, de minden hazai és külföldi kritikában és visszajelzésben dicséreteket kapott.

A kongresszus programja szerint a Mücsarnokban a tervkiállítás megnyitója szeptember 6-án (szombaton) 12 órakor volt a 10 órás Magyar Tudományos Akadémián tartott ünnepélyes kongresszusmegnyitó és a 13:30-as ebédszünet között. Az ebéd után 15 órakor a Nemzetközi Építészeti Tervkiállítás Magyar Csoportjának megnyitóját tartották meg a Nemzeti Szalonban. Másnap, szeptember 7-én (vasárnap) 11 órakor a program a Müegyetem aulájában a rektori üdvözléssel folytatódott, majd a közönség megtekintette az építészhallgatók kiállítását a délutáni svábhegyi kirándulás elött. ${ }^{13}$

Az illusztris közönség ${ }^{14}$ által is nagyra értékelt tervkiállítás több csoportból állt. A Mücsarnok adott otthont a külföldi vendégek kiállítási anyagának, és itt mutatták be a magyar modern és historizáló (eklektikus) építészek munkáit, továbbá a Müemlékek Országos Bizottsága által összeállított magyar müemlékek fényképes anyagát. A kiállítás legreprezentatívabb részét, a modern szekciót Bierbauer Virgil rendezte. Ezek mellett a Nemzeti Szalonban mutatták be a magyar stíluskeresők irányzatait, Lechner Ödön és iskolájának követőit. ${ }^{15}$ Rerrich Béla 1930. januárjában azt írta, hogy a historizáló csoportot (József nádor koráig) Fritz Oszkár rendezésével szintén a Nemzeti Szalonban tervezték elhelyezni. A magyar stíluskeresők kiállítását Kertész K. Róbert a Lechner Ödön-társasággal együttmüködésben állította össze négy részben: Feszl Frigyesről Vámos Jenő, Lechner Ödönről Gerő Ödön rendezte a kiállítást, míg Lechner Jenő a magyar történeti múltból, Györgyi Dénes pedig a népi hagyományokból merítő építészek csoportjának anyagát rendezte. ${ }^{16}$

A magyar anyag szétválasztását Gerő Ödön javasolta. ${ }^{17}$ Ennek talán a helyhiány volt az oka, hiszen a Mücsarnokban a tekintélyes mennyiségü magyar épület mellett a külföldi anyagokat is el kellett helyezni, amelyek közül több szintén igen bőséges volt. A magyar kurátorcsoport legfontosabb célja a korabeli szaksajtó alapján az volt, hogy a magyar korszerü építészetet nemzetközi viszonylatban bemutassa, megméresse, tehát a modern csoportnak mindenképpen a Mücsarnokban kellett lennie, és elképzelhető, hogy emellé még épp a historizáló és a műemléki csoport fért csak be.

\footnotetext{
${ }^{12}$ Fábián 1930. 140.

${ }^{13}$ Építö Ipar - Épitö Müvészet 54 (1930) 119-120 (augusztus 1.)

${ }^{14}$ Uo.

${ }^{15}$ Budapesti Hirlap 50 (1930) 174. (augusztus 2.) 5.

${ }^{16}$ Rerrich 1930. 11.

${ }^{17}$ Uo.
} 
A kongresszus lezárultával a legtöbb kritika a magyaros irányzatok elkülönítését érte, mivel a Nemzeti Szalonban lévő kiállításrész látogatottsága messze alulmaradt a Mücsarnokhoz képest. Ez azért volt különösen problematikus, mert a nemzeti stílus jegyében született színvonalas tervek Magyar Vilmos és Kárpáti Aurél kritikája szerint alkalmasak lettek volna Magyarország építészetének egyéni vonásait hangsúlyozni. Magyar a németek kreatív és hatékony propagandáját állította párhuzamba a kihagyott lehetőséggel, amit a magyaros csoport elkülönítése, végeredményben elrejtése jelentett. ${ }^{18}$ „,Szeretném tudni, kinek az eszméje volt ez az éles elkülönítés?” - fakadt ki Magyar hozzátéve, hogy a nemzeti szalonbeli kiállításrész megfelelő bemutatására a külföldi közönség igazán fogékony lett volna. ${ }^{19}$ A kiállítás kettéválasztása Ferkai András szerint jól szimbolizálta az építész szakma 1920-30-as évekbeli megosztottságát. ${ }^{20}$

A teljes tervkiállításról készült, többnyelvű Architectura címü katalógusba a magyaros stíluskeresők csoportjának munkáiból csak csekély kivonat került bele. Fontos azonban megemlíteni, hogy a kiadványt válogatott képanyagból állították össze, amit igazol, hogy a legtöbb külföldi ország teljesen kimaradt. ${ }^{21}$ Magyar Vilmos politikai érzelmeket sem mellőző kritikája a kiadvány összetételét, hangsúlyait is elmarasztalta. ${ }^{22}$ Mivel az Architectura a kongresszusi tervkiállítás legfontosabb forrásaként tényleg nem ad teljes képet a kiállításon bemutatott épületekről, az írásbeli beszámolók, újságcikkek szintén szubjektív válogatásai alapján egészítjük ki az egyes szekciók, országok kiállított anyagát.

\section{Magyar kiállitás a mücsarnokban, müemlékek csoportja}

A rajzokból és fényképekből álló műemléki csoportot a kiállítás gyöngyszemeként emlegették. Sikerét mutatja, hogy a dán építészek a teljes kiállítási anyagot meg akarták vásárolni, majd végül reprodukciókat készíttettek, és azt vitték magukkal. ${ }^{23}$ Kiállították Pollack Mihály eredeti rajzait a pesti Redout és a Sándor-palota belső tereiről, Myskovszky Viktor müemlékekről készített eredeti rajzait a Kunstdenkmale und Mittelalters und der Renaissance in Ungarn gyüjteményböl (1. ábra), Nádler Róbert akvarelljeit a jáki templom homlokzatáról, a pécsi székesegyház belsejéről és Laszgaller Oszkár olajképeit az Egyetemi Templom szószékéről és a Belvárosi Plébániatemplom belsejéről. A zsámbéki templomról Csányi Károly felvétele szerepelt. Láthatóak voltak továbbá: Nagyszombat templomai, a trencséni vár, a selmecbányai vár, a körmöcbányai vártemplom, a csütörtökhelyi Zápolya-kápolna, a munkácsi vár, a lőcsei városháza, Thúrzó-ház és Szent Jakab-templom, a késmárki ha-

\footnotetext{
${ }^{18}$ Magyar 1931. VI.; Magyar 1930b; Kárpáti 1930.

${ }^{19}$ Magyar 1931. VI. 22.

${ }^{20}$ Ferkai 1989. 363.

${ }^{21}$ Bierbauer 1930.

${ }^{22}$ Magyar 1930. III.

${ }^{23} 8$ órai újság 16 (1930) (szeptember 14.) 3.
} 


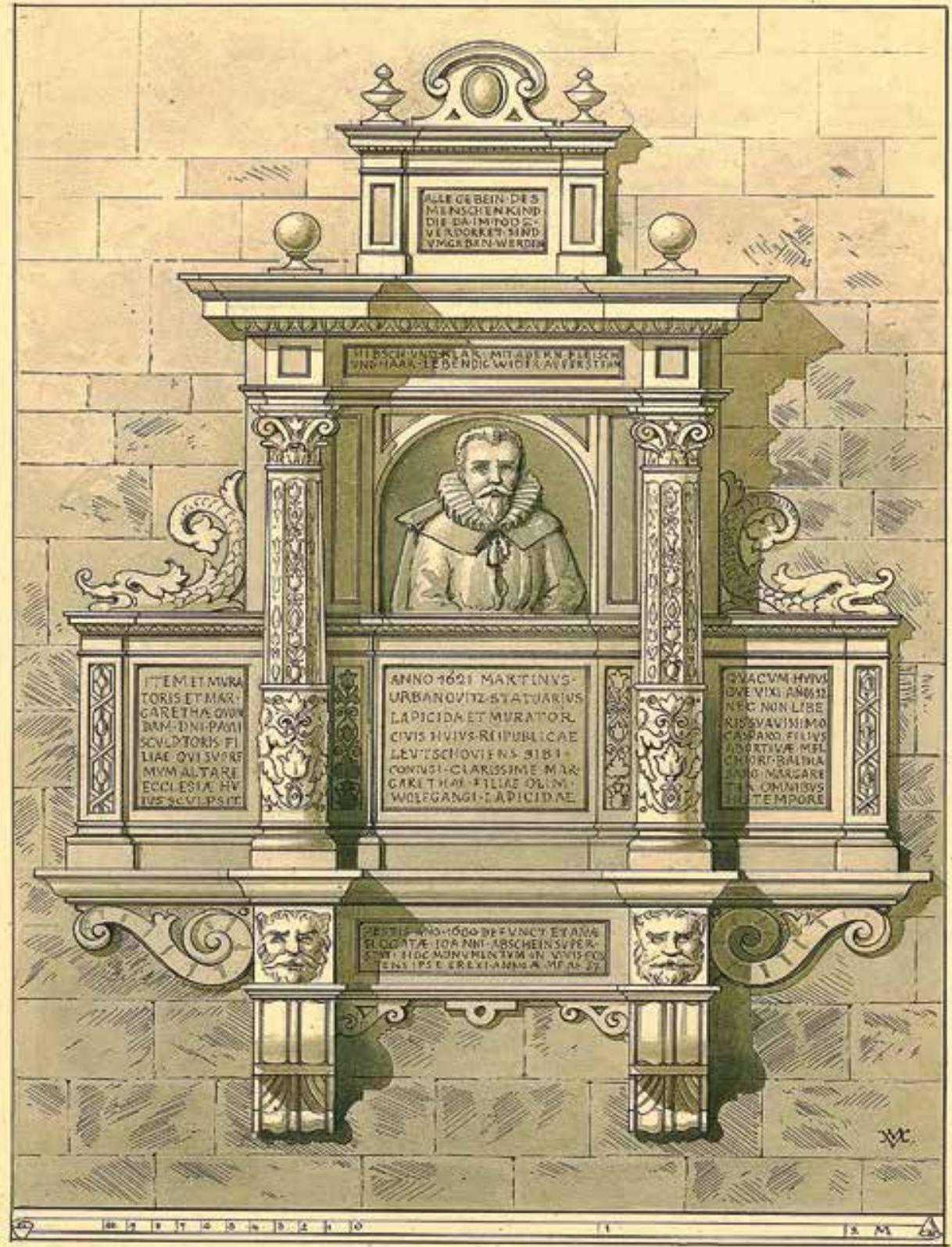

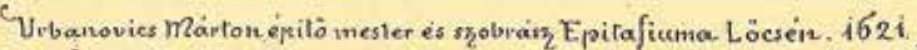

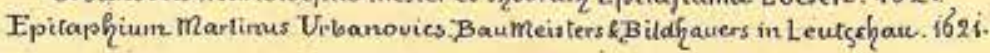

1. ábra. Myskovszky Viktor egyik rajza az Építészettörténeti Rajztárban. A Mücsarnokban kiállított Myskovszky-anyag pontos tartalmáról nincs tudomásunk. (Forrás: Építészettörténeti Rajztár 105975) 
rangtorony, Eperjes templomai, reneszánsz lakóházai, a bártfai városháza és Szent Egyed-templom, a kassai Szent Erzsébet-székesegyház és Szent Mihály-kápolna, a kolozsvári Szent Mihály-templom, a brassói Fekete Templom, a gyulafehérvári Szent Mihály-székesegyház és Károly kapu, erdélyi vártemplomok, haranglábak, kapuk, temetők, kopjafák, illetve Budapest müemlékei. ${ }^{24}$ Az Architecturában Lechner Jenő írt tanulmányt a müemléki és eklektikus csoportról. ${ }^{25}$

\section{Magyar kiállitás a Mücsarnokban, historizálók (eklektikusok) csoportja}

Ebben a csoportban főleg az akkori kortárs historizáló terveket mutatták be, amelyek között dominált a neobarokk. Magyar Vilmos kritikájában azt fogalmazta meg, hogy ,a nagy eklektikusok, a valóban hagyományokra támaszkodók”, Unger Emil, Petschacher Gusztáv, Schmahl Henrik, Láng Adolf, Schickedanz Albert, Alpár Ignác, Hauszmann Alajos, Schulek Frigyes, Pecz Samu, Lechner Ödön, Ybl Miklós és a barokkon kívül más történeti stílusok nem kaptak helyet. Az Architecturában közölt fotók a Lánchídról, az Országházról, a Nemzeti Múzeumról, a Halászbástyáról és a Tőzsdepalotáról ezek szerint nem tükrözik teljesen a bemutatott anyagot. A kiállított épületek Magyar beszámolója alapján: Korb és Girgl belvárosi palotái, Hültl Kegyesrendiek palotája, Wälder Ciszterci Gimnáziuma, Kertész K. Róbert és Sváb Gyula Gödöllői Premontrei Gimnáziuma, Szende Andor kastélyai, Komor Marcell és Jakab Dezső Pozsonyi Vigadója, Györgyi Dénes és Münnich Aladár debreceni Déri Múzeuma. ${ }^{26}$

\section{Magyar kiállitás a Nemzeti Szalonban, magyar stíluskövetők csoportja}

A szekcióról képekkel illusztrálva Magyar Vilmos számolt be részletesen. Kiállították Feszl Frigyes Vigadóját, Lechner Ödön Iparművészeti Múzeumát, kőbányai templomát, a Földtani Intézetet, a Postatakarékpénztárat, az Államvasutak Nyugdíjintézetét, a szegedi városházát, Lajta Béla müveit, Bálint Zoltán és Jámbor Lajos szatmárnémeti Vigadóját és nagybányai színházépületét, Komor Marcell és Jakab Dezső szolnoki banképületét, marosvásárhelyi Kultúrpalotáját, szabadkai városházát, Árkay Aladár Fasori Református Templomát, Rákóczi-templomát, Városmajori Templomát, győri templomát, ${ }^{27}$ Lechner Jenő Chicago tribünjét, a sárospataki tanítóképzőt, a mezőkövesdi városházát, Szent Ferenc-rendi templomát, Medgyaszay István színházait, Neuschloss-Knüsli Kornél, Zrumeczky Dezső és Kós Károly állatkerti házait, Wigand Ede kereskedelmi kamaraépületét, marosvásárhelyi Népházát, tordai földmüves iskoláját, Sváb Gyula és Györgyi Dénes iskolaépületeit, Kós Károly

\footnotetext{
${ }^{24}$ Magyar 1930a. 380; Magyar 1930. V. 13-14.

${ }^{25}$ Lechner 1930.

${ }^{26}$ Magyar 1930. V. 13.

${ }^{27}$ Farbaky 1984. 260.
} 


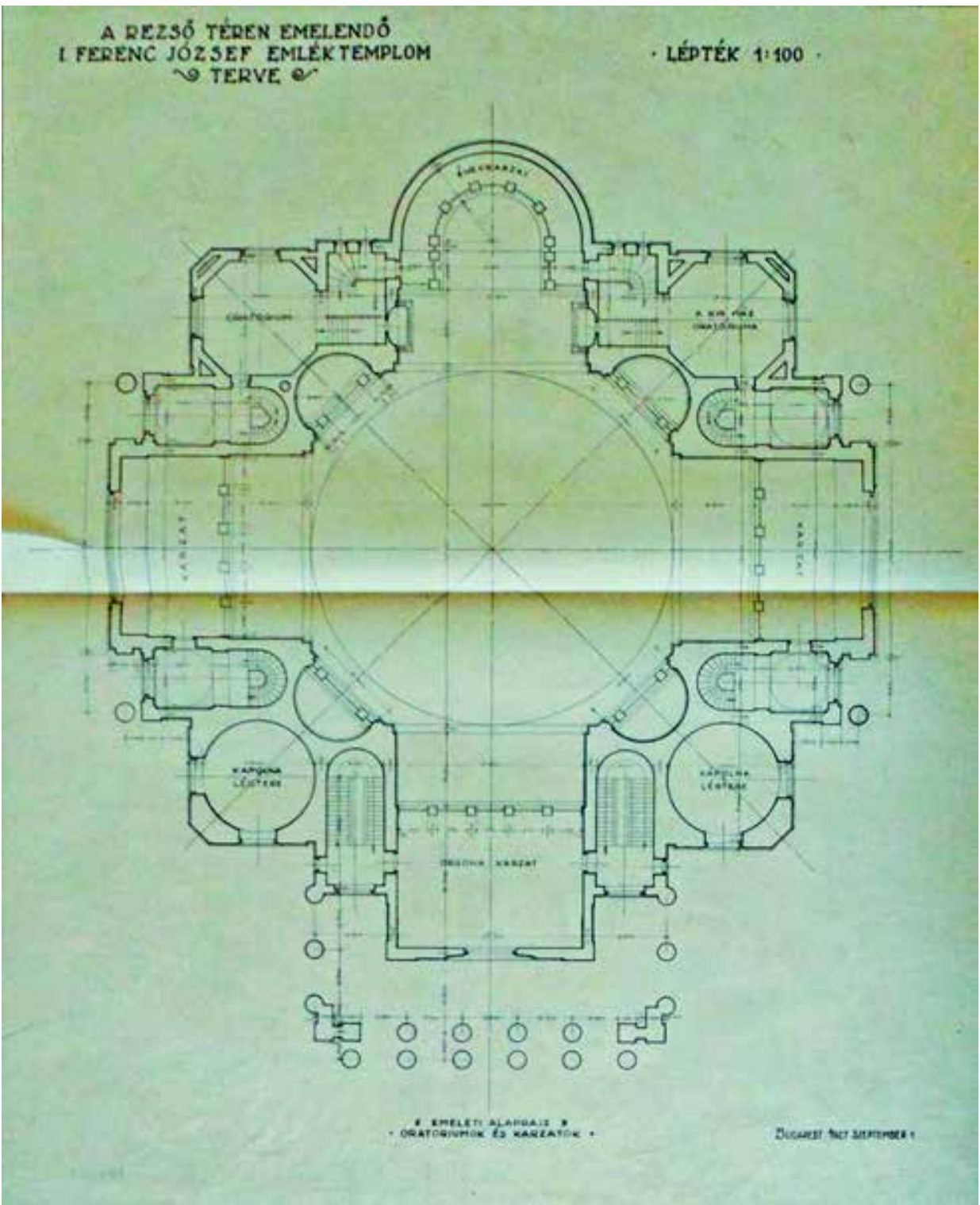

2. ábra. Kismarty-Lechner Jenő tervrajza a Rezső téri Ferenc József-emléktemplomhoz az Építészettörténeti Rajztárban (forrás: Építészettörténeti Rajztár 101423) 

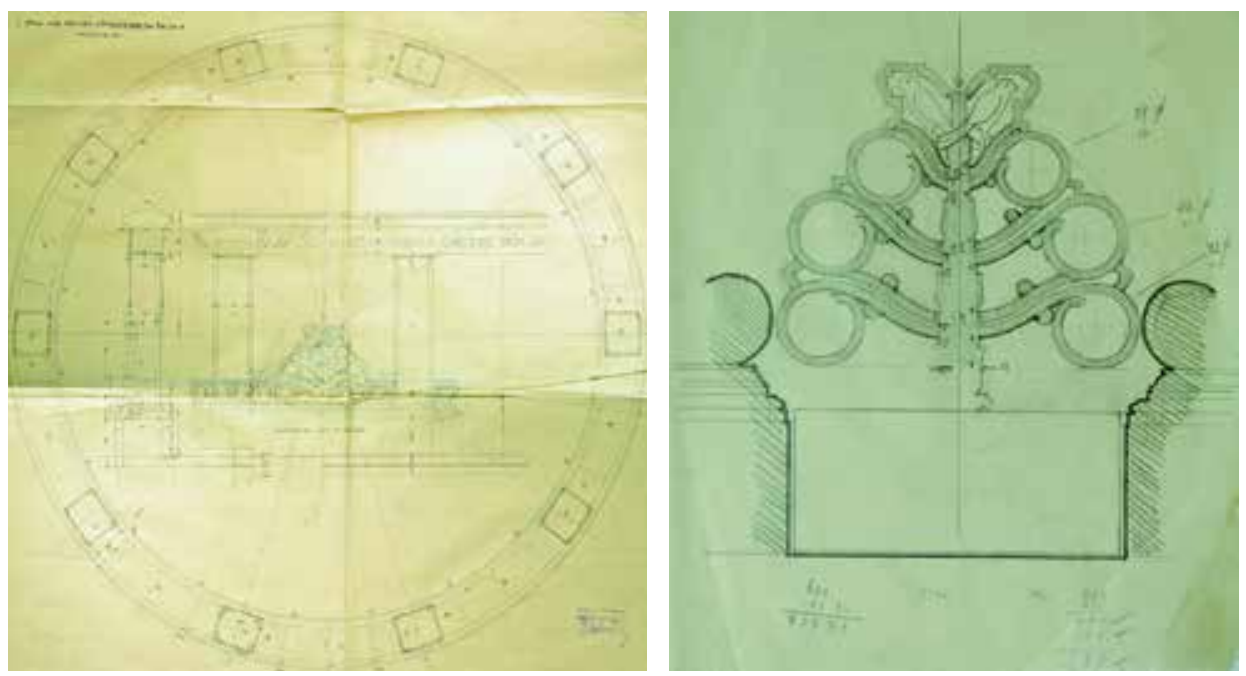

3. ábra. Kismarty-Lechner Jenő tervrajzai Jókai Mór síremlékéhez az Építészettörténeti Rajztárban (forrás: Építészettörténeti Rajztár 102108, 102190)

sepsiszentgyörgyi Székely Nemzeti Múzeumát, ketesdi és baróti református templomát. ${ }^{28}$

Lechner Jenő díjnyertes Városháza pályaterve, Ferenc József-emléktemploma (2. ábra) és Jókai Mór síremléke (3. ábra) az Architectura tanúsága szerint is szerepelt a kiállításon. ${ }^{29} \mathrm{Az}$ Építészettörténeti Rajztár mindhárom épület tervanyagából tartalmaz lapokat, skicceket. Itt található például a mezőkövesdi városházának egy színezett homlokzati tervét ábrázoló kemény tabló, amelyet a hátulján lévő felirat ${ }^{30}$ alapján 1939-ben állítottak ki a Mücsarnokban. Felvethető, hogy a tabló - kiállítási anyag lévén - esetleg ezt megelözően, az 1930-as tervkiállításon is szerepelhetett, habár erre vonatkozóan konkrét tények egyelöre nem ismertek (4. ábra).

\section{Magyar kiállitás a Mücsarnokban, modernek csoportja Modern törekvések címmel}

Kotsis Iván önéletrajzi írása is utal rá, de a tervkiállítás sajtóvisszhangjából is leszürhető, hogy a modern szekció és a külföldi építészettel való összehasonlítás a magyar építészszakmában kisebbségi érzéseket keltett. Kotsis eleinte nem is támogatta a kongresszus Budapesten történő szervezését, mert úgy gondolta, a magyar építészet színvonala elmaradt a külföldiétől. A mücsarnoki kiállításon a legerösebb-

${ }^{28}$ Magyar 1931. VI. 20.

${ }^{29}$ Bierbauer 1930. 70-71; Tér és Forma 3 (1930) 9. (szeptember) 388.

${ }^{30}$ „A mezökövesdi városháza díjnyertes pályaterve; tervezte: Dr Lechner Jenö”; Vignettán: „Öszi Csoportos kiállitás, Mücsarnok 1939. 276." 


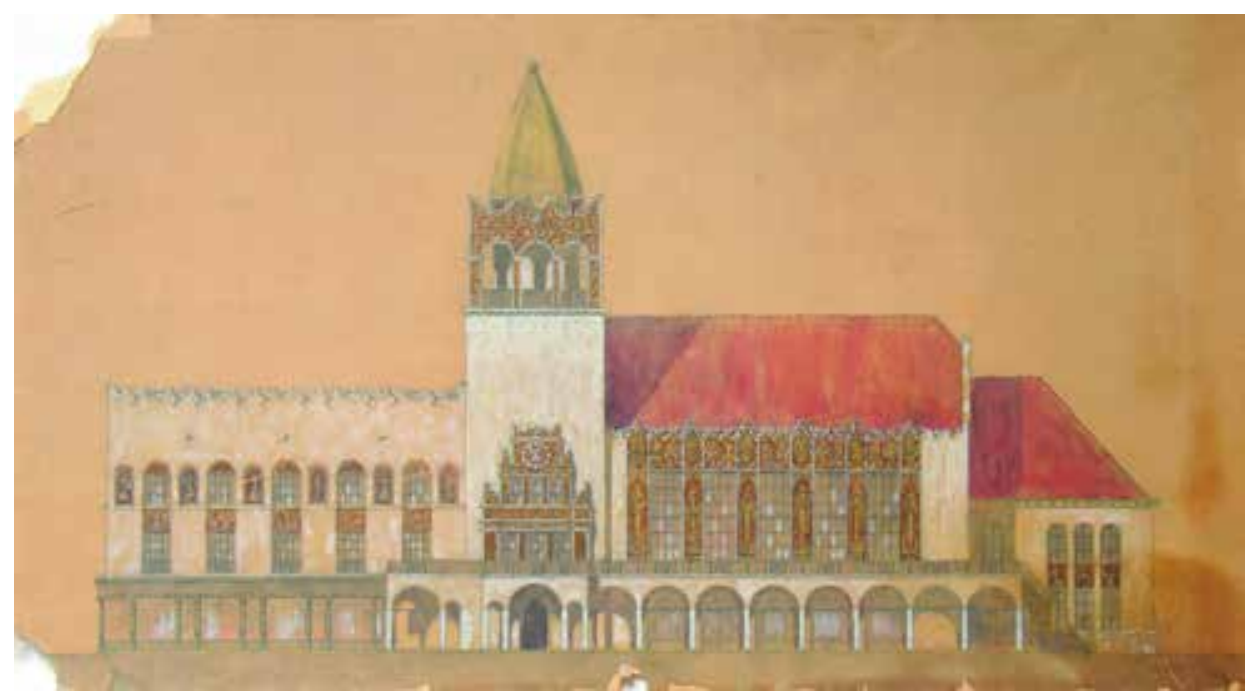

4. ábra. Kismarty-Lechner Jenő Mezőkövesdi Városháza-terve (forrás: Építészettörténeti Rajztár 102096)

nek és valóban büszkeségre okot adónak a historizáló csoportot tartotta, a modern szekciót azonban siralmasnak találta a többi országéhoz képest. ${ }^{31} \mathrm{Az}$ igazán kritikusan szemlélő Magyar Vilmos ezzel szemben a magyar anyag külföldihez viszonyított nívóját ,, a legtárgyilagosabb itélettel is, igen kedvezö"-nek titulálta, amivel méltán büszkélkedhettünk, annál is inkább, mivel Magyarországon tulajdonképpen már a világháború előtt is épültek tisztán modern épületek, ezzel megelőzve Németországot, Hollandiát vagy Franciaországot. ${ }^{32} \mathrm{~A}$ finn kiküldött, Carolus Lindberg szerint szintén szakszerüen rendezett és gazdag volt a magyar modernek csoportjának anyaga. ${ }^{33} \mathrm{Az}$ aggodalom, amely szerint a magyar építészet nem lett volna elég modern a nemzetközi porondon, a kiállítás megnyitásakor értelmét vesztette. Magyar Vilmos szerint ugyanis a tervkiállítás összességében megmutatta, hogy a modernizmus külföldön 1930-ban már lecsengett, a hangsúly már a sivárság elkerülésén és az egyéniségek, nemzeti sajátosságok megmutatásán volt, éppen ezért aratott olyan nagy sikert a magyarok többi szekciója, a historizáló és a müemléki csoport. ${ }^{34}$ A kiállított épületek sora: Árkay Aladár és Körmendy Nándor győri színházterve, Arvé Károly és Gerstenberger Ágost margitszigeti fedett uszodaterve, Hajós Alfréd margitszigeti fedett uszodaterve, Gyenes Lajos Szabadság téri rendezési terve, Komor Marcel és Komor János madridi szabályozási terve, Orbán Ferenc tárházai, Lajta, Pogány és

\footnotetext{
${ }^{31}$ Prakfalvi 2010. 199. Kotsis életrajzának részleteit a Lapis Angularis sorozat I. kötete is közölte, de a szöveg nem egyezik meg teljesen az életrajzi kiadás szövegével. Hajdú-Prakfalvi 1995. 252-253.

${ }^{32}$ Magyar 1930a. 378 és Magyar 1931. V. 12.

${ }^{33}$ Turán 13 (1930) 1-4. 67.

${ }^{34}$ Magyar 1930. IV. 189.
} 
Tőry Nemzeti Színház-terve, Hültl Dezső autóbuszgarázsa, Györgyi Dénes barcelonai kiállítási pavilonja, Lauber László Excelsior Fehérvári úti benzinkútja. ${ }^{35}$

\section{Külföldi építészek kiállitása a Mücsarnokban, Németország}

A nemzetiközi tervkiállításon a magyar csoporton kívül két tucat vendég ország közel 2000 tervvel szerepelt. ${ }^{36}$ Kotsis Iván visszaemlékezése szerint a legbőségesebb anyagot a németek hozták. Nagyméretü fotóikkal igen hatásos kiállítást rendeztek, aminek teljes anyagát Kotsisnál hagyták a kongresszus után, aki azokat később oktatási anyagként használta. ${ }^{37}$ A német összeállítás Magyar Vilmos szerint is kiemelkedő volt, különösen a mennyiséget és a minőséget tekintve. A németek szereplésének legnagyobb eseménye Fritz Höger téglaépítészetről ${ }^{38}$ és German Bestelmeyer müncheni rektor „Az újabb német épitészetről”39 tartott előadása volt. Bestelmeyer előadása alapján leszürhető volt, hogy a modern építészet 1930-ban még Németországban is komoly útkeresési fázisban volt. A történeti stílusok elvetésével és az új technikával megjelenő modern építészetet építőmüvészet helyett építőtechnikának nevezte, ami fontos meglátás a modernizmus melletti más, gazdagabb díszítőmüvészetet integráló építészeti irányzatok elfogadása tekintetében. ${ }^{40}$ Komor Marcell 1929ben a Tér és Formában írt cikkében lényegében csak a modern, múltbéli hagyományoknak hátat fordító építészetet tartotta müvészetnek. ${ }^{41}$ Bestelmeyer előadásában azt is kimondta, hogy habár már kialakult a díszítőelemek nélküli, tisztán szerkezeti konstrukció pozitív esztétikai megítélése, az új stílus tudatos megalkotására tett modern kísérletek zátonyra futottak, mert a stílus természetéböl fakadóan alakul ki, önkényesen nem teremthető meg. Hültl Dezső müegyetemi rektori székfoglaló beszédében ehhez a gondolathoz csatlakozva tette hozzá, hogy a teljes lecsupaszítás már a nagyközönségnek sem tetszik, és bizonyos mértékü díszítésre igenis szükség van. ${ }^{42}$ Kiállított épületek: Hubert Ritter és Franz Dischinger lipcsei nagyvásárcsarnoka, Eugen Schmoll berlini Ullstein-nyomdája, Mossner müncheni repülőgépcsarnoka, Erich Mendelsohn Schocken (Chemnitz) áruháza, Fritz Höger hamburgi Bürohaus Sprinkenhofja, stuttgarti Paul Bonatz pályaudvara, delmenhorsti temetőkápolnája és rustringeni városházája, Hans és Oscar Gerson hamburgi Ballinhaus-terve, Bruno Paul gelsenkircheni Kathreiner irodaháza, Heinrich Tessenow St. Moritz-i (Engadin) lakóházának terve, Wilhelm Kreis drezdai múzeuma, Oscar Kaufmann berlini színházai, Ludwig Ruff bambergi szemináriumépülete, German Bestelmeyer prieni evan-

\footnotetext{
${ }^{35}$ Magyar 1930a. 380; Magyar 1931. V. 12-13.

${ }^{36}$ Magyar 1930. IV. 189.

${ }^{37}$ Prakfalvi 2010. 199.

${ }^{38}$ Magyar 1930. I. 148-149.

${ }^{39}$ Hültl 1930a. 156.

${ }^{40}$ Magyar 1930. II.

${ }^{41}$ Komor 1929.

${ }^{42}$ Hültl 1930a. 156.
} 
gélikus temploma, Hans Herkommer Frankfurt am Main-i Friedenskirchéje, Albert Boßlet würtzburgi missziós temploma, Heinrich Strunck és Josef Wentzler belgrádi katedrálisának I. díjas pályaterve. ${ }^{43}$

\section{Külföldi épitészek kiállitása a Mücsarnokban, Hollandia}

A holland kiállítás szintén nagy mennyiségủ anyagot tartalmazott, áttekinthetőségben azonban elmaradt a németekétől. A kiállított épületek: Hendrik Petrus Berlage hágai Christian Science temploma, Johan Melchior van der Mey amsterdami Hajózási Irodaháza, Piet Kramer amsterdami bérháza, de Byenkorf hágai áruházépülete, Willem Marius Dudok hilversumi városháza- és iskolatervei, Johannes Andreas Brinkman és Leendert van der Vlugt van Nelle gyártelepépületei, az Amsterdami Városi Mérnöki Hivatal ipariskolája. ${ }^{44}$

\section{Külföldi épitészek kiállitása a Mücsarnokban, Olaszország}

Kiállított épületek: Giovanni Muzio milánói hősi emléke és a milánói Universitá Cattolica del Sacro Coure épülete, Alessandro Limongelli tripoliszi diadalkapuja, Francesco Fichera cataniai kereskedelmi intézete, Ottavio Cabiati és Alberto Alpago milánói kiállítási pavilonja. ${ }^{45}$

\section{Külföldi épitészek kiállitása a Mücsarnokban, Ausztria}

Magyar Vilmos szerint az osztrák szekció volt a legtisztábban modern a mücsarnoki kiállitáson, mivel szerinte még a német anyagban is voltak hagyományos, olykor historizáló alkotások. Kiállított épületek: Rudolf Frass bécsi Hochhaus-terve, Hans Vetter bécsi villája, Hubert Gessner linzi munkáskamarája, Franz Koppélhuber steyri krematóriuma, Hermann Tamussino mödlingi városi fürdője. ${ }^{46}$

\section{Külföldi épitészek kiállitása a Mücsarnokban, Svédország}

A svédek kiállitási anyaga a nemzeti hagyományokat és a modernséget ötvözte. Kiállított épületek: Ivar Tengbom stockholmi koncertháza és a Chilehaus, Birger Jonson stockholmi Philadelphia temploma, Ragnar Östberg stockholmi városházája. ${ }^{47}$

\footnotetext{
${ }^{43}$ Magyar 1930a.

${ }^{44}$ Magyar 1930a. 379.

${ }^{45}$ Uo.

${ }^{46}$ Magyar 1930a. 379.

${ }^{47}$ Uo.
} 


\section{Külföldi építészek kiállitása a Mücsarnokban, Finnország}

A 40 darabból álló csoport nem adott teljes képet a színvonalas finn építészetről, Eliel Saarinen épületei közül például egyet sem állítottak ki. ${ }^{48}$ Kiállított épületek: Johan Sigfrid Sirén helsinki parlamentje, Oiva Kallio és Kauno S. Kallio imatrai vízierőmü telepe, M. N. Borg kotkai népiskolája. ${ }^{49}$

\section{Külföldi épitészek kiállitása a Mücsarnokban, Norvégia}

Magyar Vilmos szerint a skandináv országok közül Norvégia őrizte meg legjobban nemzeti sajátosságait a kiállítási anyag alapján. A 131 darabos norvég gyüjtemény egy 1925-ben alapított vándorkiállítási anyag volt, ami más rangos kiállításokon is szerepelt szerte a világon. A rajzokból, fotókból és 6 gipszmodellből álló csoport a

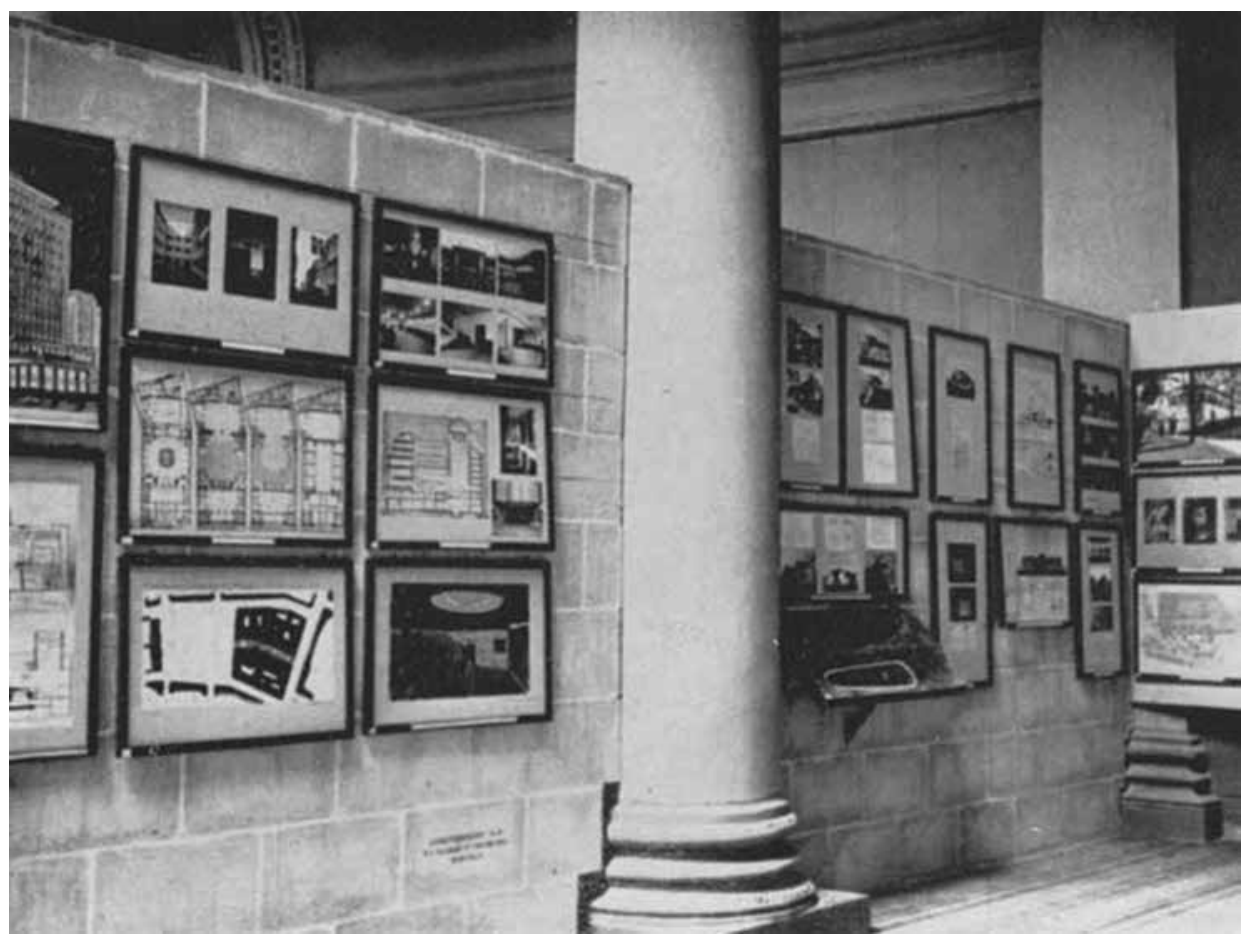

5. ábra. A norvég szekció kiállítása a Múcsarnokban (forrás: Lending 2014)

(Eredeti hivatkozása: XII Congrès international des architectes Budapest 1930. Compte-Rendu: Travaux du XII Congrès international des architectes. Budapest 1931.)

${ }^{48}$ Turán 13 (1930) 1-4. 67.

${ }^{49}$ Magyar 1930a. 380. 
mücsarnoki kiállítás harmadik legnagyobb szekciója volt ${ }^{50}$ (5. ábra). A kiállított épületek: Henrik Nissen strukkéliai erdei kápolnája, Ole Landmark bergeni múvészeti múzeuma, Magnus Paulson grani temploma, sandvikai városházája, Ree és Buch vågå-i vadászlakja. ${ }^{51}$

\section{Külföldi épitészek kiállitása a Mücsarnokban, Lengyelország}

Magyar véleménye alapján a lengyelek csoportja volt a legízlésesebb. Kiállították Stanisław Witkiewicz modern munkáit, Tadeusz Makowski lengyel müemlékekröl készült ecsetvázlat-sorozatát és Dugat Antonin varsói Grafikai Intézetét. ${ }^{52}$

Külföldi épitészek kiállitása a Mücsarnokban, Csehszlovákia

Az Architectura böséges képanyaggal mutatta be Csehszlovákia kiállított épületeit. Magyar Vilmos heves, politikai tekintetben is véleményformáló kritikájában felrótta a csehszlovák anyag ilyen nagy mennyiségben történő közlését, ami éles kontrasztban állt szerinte az északi szomszédok - akkortájt tapasztalható - magyar kultúra elleni bojkottjával. ${ }^{53}$

\section{Külföldi épitészek kiállitása a Mücsarnokban, Jugoszlávia}

A kiállított épületek: Kaularic szabályozási terve Zágráb piacára, Futur-Kos jenicei temploma, Jože Plečnik újvidéki színházterve, Ulrich spliti fürdője. ${ }^{54}$

Külföldi épitészek kiállitása a Mücsarnokban, Belgium, Franciaország, Anglia, Románia, Görögország és Amerika

Ezeknek az országoknak a kiállításáról még Magyar Vilmos sem adott bővebb információt, a kiállított épületek közül nem emelt ki konkrét alkotásokat. Belgium, Franciaország és Anglia építészetének évszázados hagyományokkal rendelkező egyediségét a kiállítás is tükrözte, Görögország anyagát azonban várakozáson alulinak, közepesnek értékelte, és Romániáéban sem talált semmi eredetit. Amerika építészeti alkotásai léptékükben messze túlszárnyalták az itthoniakat, emellett pedig

\footnotetext{
${ }^{50}$ Lending 2014.

${ }^{51}$ Magyar 1930a. 380.

${ }^{52}$ Magyar 1930. IV. 191.

${ }^{53}$ Magyar 1931. VII.

${ }^{54}$ Magyar 1930. IV. 191.
} 
látszott, hogy az Amerikára ható európai áramlatok mellett az európai anyagon is megmutatkozott a tengeren túli kontinens építőmúvészetének visszahatása. ${ }^{55}$

\section{Építészhallgatók terveinek, rajzainak kiállitása a Királyi József Müegyetemen}

A Mücsarnok és a Nemzeti Szalon mellett egy harmadik helyszínen is rendeztek kiállítást a kongresszus közönségének. Ezt a Magyar Királyi József Müegyetem hallgatóinak terveiből és rajzaiból Kotsis Iván nyilvános rendes tanár állította össze a Mủegyetem aulájában. ${ }^{56}$ Ezen leginkább a tervezési tantárgyak korszerüség jegyében született évközi tervei és szigorlati tervek kaptak helyet, tanszékek és vezető tanárok szerint rendezve ${ }^{57}$ mivel a kiállítás célja az volt, hogy bemutassa az oktatás színvonalát, illetve azt, hogy az építészképzés mennyire lépést tart a modern irányzatokkal. ${ }^{58}$ A hallgatói kiállítás aktualitását ezenkívül a kongresszus első számú napirendi pontja adta, amely az új, speciális építőtechnológiák világában az oktatás új feladatait és korlátait fogalmazta meg.

Kotsis szerint, aki az Építészi Osztály tanári karával együtt rendezte a kiállítást, végeredményben a külsőségekre sikerült nagyobb hangsúlyt fektetni, pedig ő eredetileg a tartalomra próbált koncentrálni. A tervek bemutatása egységes volt, az egész anyag rajztechnikailag magas színvonalú volt. Kotsis visszaemlékezése és a tervanyagból összeállított katalógus szerint is ,kizárólag perspektívák”-at mutattak be. ${ }^{59}$ A közönséget - valószínüleg leginkább a szeptember 7-i megnyitón - Kotsis kalauzolta a Müegyetem aulájában. A kiállítás általános elismerést váltott ki, ${ }^{60}$ bár Kotsis önéletrajzi írásában úgy emlékezett vissza, hogy a külföldi sajtó ,„üvegházi kitenyésztés"'-nek értékelte a terveket. ${ }^{61} \mathrm{Az}$ olasz vendégek azonban úgy vélekedtek, hogy „,Nem szárnypróbálgatások [voltak] ezek, hanem eröteljes tudás szárnycsapásai." ${ }^{\circ 2}$

A Mủegyetem hallgatóinak kiállítása azonban nemcsak a tervekből állt, valójában két részből tevődött össze, amiről a korabeli sajtóból is csak igen kitartó gyüjtőmunkával értesülhetünk. ${ }^{63} \mathrm{~A}$ tervek csoportja mellett a másik, kisebb mennyiségű részben a képzés más tantárgyaihoz kapcsolódó rajzokat mutatták be, amiről csak az Építő Ipar-É - pitő Müvészet 1930. június 1-jei számában lehet olvasni. ${ }^{64}$ Úgy tünik, hogy a tervezésoktatáson túl a mủegyetemi kiállítással teljes képet próbáltak nyújtani a képzésről a kongresszus látogatói számára. A második csoportban a szerkezeti és

\footnotetext{
${ }^{55}$ Magyar 1930. IV. 191.

${ }^{56}$ Épitö Ipar - Épitö Müvészet 54 (1930) 21-22. (június 1.) 87. Krónika rovat.

${ }^{57}$ Magyar Iparmüvészet 33 (1930) 162; Épitö Ipar - Épitö Müvészet i. h.

${ }^{58}$ Budapesti Hirlap 50 (1930) 201. (szeptember 15.) 4.

${ }^{59}$ Kotsis 1930 b.

${ }^{60}$ Magyar Iparmüvészet 33 (1930) 162.

${ }^{61}$ Prakfalvi 2010. 200.

${ }^{62} 8$ órai újság 16 (1930) (szeptember 14.) 3.

${ }^{63}$ Építő Ipar - Épitő Müvészet 54 (1930) 21-22. (június 1.) 87. Krónika rovat.

${ }^{64}$ Uo.
} 
statikai, az építőművészeti és a rajzbeli tárgycsoport tárgyait helyezték el. ${ }^{65}$ Arról, hogy az építészettörténeti tárgycsoport munkáit is kiállították, konkrétan sehol sem olvashatunk, az Építészettörténeti Rajztár öt nyelven feliratozott, egységes kivitelü tablósorozata azonban erre utal.

\section{ÉPÍTÉSZETTÖRTÉNETI TABLÓSOROZAT (TALÁN) AZ 1930-AS MÜEGYETEMI KIÁLLÍTÁSRÓL}

A szóban forgó, 22 darabból álló tablósorozat az Építészettörténeti Rajztárban a 103242-103263-as jelzet alatt található. A tablók kiképzése, feliratozási rendszere egységes. A sorozatban építészettörténeti rajzok vannak, melyeket barna színü, vastag kartonokra kasíroztak. A szerzők (hallgatók) nevét, évfolyamát és a rajz témáját a tablók alsó részén lévő egyen-feliratpecsétre írták egységes grafikával magyarul, németül, angolul, franciául és olaszul. Az anyag egységes formátuma, feliratozási kultúrája és keltezései is arra engednek következtetni, hogy az 1930-as müegyetemi kiállításon szerepeltek.

A tablók részletes leírását és fényképes reprodukcióit cikkünk melléklete tartalmazza.

A rajzok leginkább a középkori tantárgycsoporthoz tartoznak, középkori fejezeteket, gyámköveket, vízköpöket, fiatornyokat, keresztrózsákat és más alaktani részleteket, épületrészeket tartalmaznak. Teljesebb épületábrázolás csak a Hagia Szophia, ${ }^{66}$ Diocletianus fürdöjének rekonstrukciója, ${ }^{67}$ a vajdahunyadi vár, ${ }^{68}$ valamint a csütörtökhelyi Zápolya-kápolna ábrázolásánál van. A tablókon lévő rajzokat láthatóan tematikusan válogatták össze, az alsó pecséten a következő kategóriák olvashatók: Középkori oszlop és pillérlábazatok (1 lap); Példák gót külföldi emlékek közül (1 lap); Mérmüves ablakok (2 lap); Rekonstrukciós feladat (1 lap); Középkori fejezetek (3 lap); Középkori kapukiképzések (2 lap); Végzödések és fiale csoportok (1 lap); Középkori párkányok (1 lap); Figurális kiképzésü gyámkövek (1 lap); Növénydíszitésü gyámkövek (1 lap); Famennyezetek (1 lap); Kúszólevelek és vizköpök (1 lap); Rózsaablak (1 lap); Keresztvirágok (1 lap); Példák gót hazai emlékek közül (2 lap); Példák gót profán épitkezésböl (1 lap); Példák bizánci emlékek közül (1 lap). Több lapon olvasható és a dátumból leszürhető, hogy a rajzok egy részét a második évfolyamos Középkori építészet I nevü, két féléves tantárgy tavaszi kurzusának feladataként készítették. ${ }^{69} \mathrm{~A}$ tablók nagy részét másodévesek rajzolták, csupán három rajz készült harmadéves tárgy keretében: a csütörtökhelyi Zápolya-kápolna alaprajza és homlokzata és a Hagia Szophia metszete. ${ }^{70} \mathrm{~A}$ teljes anyagot tekintve úgy tünik, hogy

\footnotetext{
${ }^{65}$ Uo.

${ }^{66}$ Építészettörténeti Rajztár 103250.

${ }^{67}$ Építészettörténeti Rajztár 103253.

${ }^{68}$ Építészettörténeti Rajztár 103246.

${ }^{69}$ Építészettörténeti Rajztár 103254, 103256.

${ }^{70}$ Építészettörténeti Rajztár 103248, 103249, 103250.
} 
a második évben a Középkori építészet I tantárgyak keretében föleg az alaktan és a szerkezeti részletek elsajátítása volt a cél, amihez épületrészeket vagy kisebb részleteket, szerkezeti elemeket (mérmüves ablakok, fejezetek, lábazatok, párkányok, mennyezet, vízköpők) kellett rajzolni. A harmadik évben a Középkori építészet II két félévében már teljes épületek rajzolása lehetett a feladat az előzó évben megtanult alaktan felhasználásával.

A kiállítási tablókon kívül más hallgatói rajzok is fennmaradtak az 1920-as évekből, amelyek segítenek teljesebb képet alkotni a tananyagról. 1927-ből ifj. Lechner Jenő középkori párkányokat ábrázoló második évfolyamos rajza is mutatja például, hogy a Középkori építészet I-es tárgycsoport az alaktant és a szerkezeti részleteket tanította. ${ }^{71}$ Egy, a monrealei dómról készült 1927-es hallgatói rajz pedig valószínűleg a Középkori építészet II egyik félévében készülhetett. ${ }^{72}$ A 9 félévből álló tanrendet Kotsis Iván az 1930-as müegyetemi kiállítás katalógusában részletesen leírta. ${ }^{73}$ Eszerint a hallgatók az első évben a két féléves Ókori építészet I-gyel kezdték meg építészettörténeti tanulmányaikat. A második évfolyamban az Ókori építészet II ( 2 féléves) mellett már a Középkori építészet I-et is hallgatták. A harmadik évben az ókor elhagyásával a Középkori építészet II-vel és az Újkor I-gyel folytatódott a tanrend mind a két félévben. A negyedik évben már csak az Újkori építészet II maradt. Ekképpen mindhárom korszakból összesen négy-négy félévet tanultak. Az ókor tanszéknek Wälder Gyula, a középkor tanszéknek Möller István, az újkor tanszéknek pedig Hültl Dezső volt a tanszékvezetője. ${ }^{74}$ A tablók közül többet egy mind ez idáig azonosítatlan tanár látott el szignójával. Az egyetlen téma, ami kissé kilóg a sorból, az a Diocletianus-therma rekonstrukciós rajza. ${ }^{75}$ Hogy melyik tantárgy keretében volt feladat rekonstrukciók rajzolása, illetve hogy miért csupán egy antik épület szerepel a tablósorozaton, nyitott kérdés marad, amire az Építészettörténeti Rajztár teljes katalógusát tekintve sem tudunk választ adni. Diocletianus thermája ezenkívül még szerepel egy olyan hallgatói rajzon, ami 1927-ből maradt fenn. ${ }^{76}$ Hasonló tematikát mutatnak a nîmes-i Maison Carrét, Antonius és Faustina templomát és Octavius kapuját ábrázoló hallgatói rajzok 1928-ból, 1927-ből és 1924-ből. ${ }^{77}$ Az utóbbi kettő felirata bizonyítja, hogy az Ókori építészet II. félévének feladatára készültek. Ezek mellett fennmaradtak ifj. Lechner Jenő első évfolyamos hallgatói rajzai is 1926-ból, amelyek görög ión oszloprendet és görög dór stílusban tervezett kisebb épület tervét ábrázolják. ${ }^{78}$ Ezek alapján úgy tünik, hogy az ókori tárgycsoportban a középkorihoz hasonlóan az első félév(ek)ben szerkezeti elemek, alaktan rajzolása volt a feladat, majd később, ezekre építve teljes épületek, rekonstrukciók rajza és még mindig stí-

\footnotetext{
${ }^{71}$ Építészettörténeti Rajztár 102236.

${ }^{72}$ Építészettörténeti Rajztár 103126.

${ }^{73}$ Kotsis 1930b. 6-7.

${ }^{74}$ Uo.

${ }^{75}$ Építészettörténeti Rajztár 103253.

${ }^{76}$ Építészettörténeti Rajztár 102313.

${ }^{77}$ Építészettörténeti Rajztár 102306, 102310, 102318-102319.

${ }^{78}$ Építészettörténeti Rajztár 102235, 102237.
} 
lusban tervezés volt a tananyag. A stílusban tervezési feladatok két világháború közötti továbbélését egy 1926-ból származó középkori témájú hallgatói terv is alátámasztja (vidéki városháza terve), amelyen Möller István professzori szignója látható. ${ }^{79}$

A tablók arról is tanúskodnak, hogy az építészhallgatók építészettörténeti rajzai hogyan változtak meg a 19. századi kezdetektől a két világháború közötti időszakra.
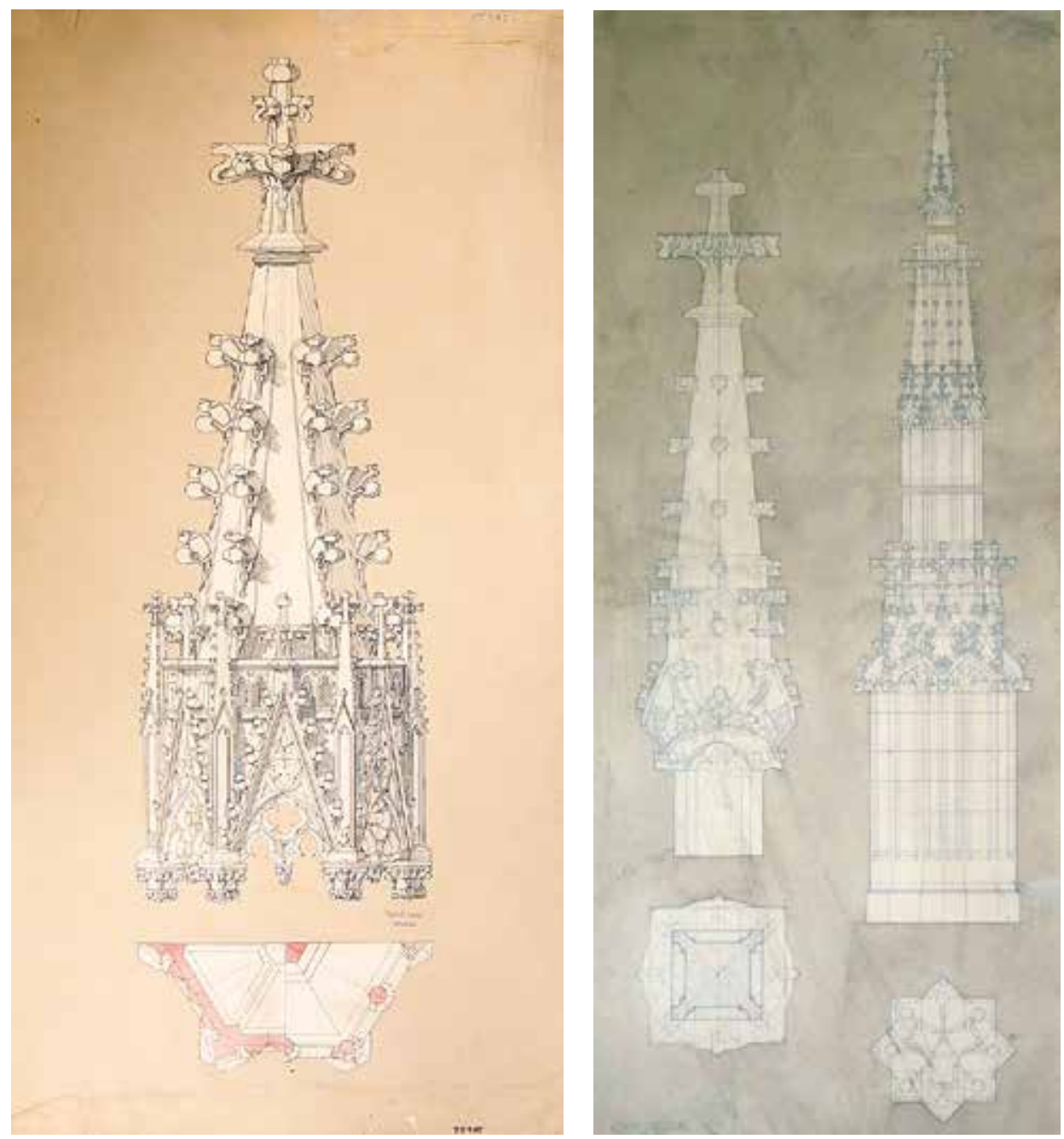

6. ábra. Gótikus részletrajzok Steindl hagyatékából és az 1930-as tablósorozatból (forrás: Építészettörténeti Rajztár 104038 és 103251)

${ }^{79}$ Építészettörténeti Rajztár 102242-102243. 
A tervezési feladatok ábrázolásánál a modern szemlélet gyökeresen átformálta a professzionális és a hallgatói tervek grafikáját. Az akvarellel és művészi részletességgel, gyakran virtuóz módon megalkotott 19. századi rajzokat (amelyekre Pollack 1930-ban nagy elismerést kiváltó, Mücsarnokban kiállított rajzai is példák lehetnek $^{80}$ ) a modern szellemiség jegyében az erős grafikával fény-árnyék hatást felerősítő, kontrasztosságra és plasztikusságra törekvő rajzok váltották fel. Ez a szemléletváltás leginkább a rajztári tablócsoport vastag hegyủ tustollal kihúzott alaktani részletrajzain figyelhető meg. Vannak aprólékos igényességgel kivitelezett munkák is, például a középkori famennyezetet ábrázoló 103256-os jelzetű rajz, amelynek pontos és részletekbe menő szerkezethelyes ábrázolása még a 19. századi technikát idézte, egyre általánosabbá váltak azonban a nagyobb felületekre koncentráló, expresszív grafikájú rajzok. Ezzel párhuzamosan megfigyelhető, hogy az építészettörténeti rajzok fokozatosan elvesztették szerkezeti jellegüket, és inkább az alaktanra, a részletek díszítő jellegére koncentráltak. Ez a folyamat természetesen a 20. század eleji építészetelméletben is lejátszódott szemléletváltásra reflektált, ami az elavultnak titulált historizáló tervezést tévesen csak a díszítőelemek másolásaként kezelte, meg nem értve annak mélyebb szerkezeti tartalmait. Az építészettörténeti hallgatói rajzok többsége sajnálatos módon elkezdte nélkülözni a konstrukció értő ábrázolását, és a régi mintalapok egyszerüsített másolatává vált (6. ábra). Egyes rajzokon visszakövethető, mely mintalapokról másolták. Ilyen például a 103262-es jelzetü gyámköveket ábrázoló tabló, amelyen az első rajz, a vajdahunyadi sárkányos gyámkő „eredetije" a Wiener Bauhütte VI. évfolyam II. szemeszterében található. A vajdahunyadi országház alaprajzát szintén ugyaninnen, a Friedrich von Schmidt-tanítványok 1860as években készült vajdahunyadi felmérései után rajzolhatták. A vajdahunyadi vár csigalépcsőjének kapujáról is készült hallgatói rajz a két világháború között, ${ }^{81}$ aminek eredetijét szintén a jóval részletesebben kidolgozott 19. századi mintalapok között kereshetjük. ${ }^{82}$ Hasonlóképpen mintalapok alapján készültek a tablósorozat Zápolya-kápolnát ábrázoló rajzai is ${ }^{83}$ Ennek az épületnek egyik legelső felmérési rajzát 1862-ben még Schulek Frigyes készítette el hallgató korában. ${ }^{84}$

\section{KORTÁRS ÉS TÖRTÉNETI}

A Budapesten megrendezett XII. Nemzetközi Építészkongresszus híven tükrözi a magyarországi építész körök két világháború közötti megosztottságát. ${ }^{85} \mathrm{~A}$ szakma képviselöi a műegyetemi építészképzéstől azt várták, hogy folyamatosan megújulva kövesse le az iparban lejátszódó, felgyorsult folyamatokat. A tanrend reformja nemcsak az

\footnotetext{
${ }^{80}$ Magyar 1931. V. 14.

${ }^{81}$ Építészettörténeti Rajztár 103144.

${ }^{82}$ Építészettörténeti Rajztár 103152.

${ }^{83}$ Építészettörténeti Rajztár 103248-103249.

${ }^{84}$ Építészettörténeti Rajztár 101752.

${ }^{85}$ Ferkai 1989.
} 
1920-as és 1930-as években volt aktuális, hanem, ahogyan napjainkban is, a jelenkori technológiai változásokra kellett nyitottnak lenni. Általában a legtöbbször felmerülő kérdés az egyes szakági tantárgycsoportok óraszámáról, esetleg szükségességéről szól.

Az építészettörténet és a mindenkori kortárs tervezés viszonya a 19. századi állapothoz képest teljesen megváltozott, és a történeti építészeti tárgycsoport kurzusainak mennyiségét, létjogosultságát már az 1930-as tanrendreform idején is szükségessé vált megindokolni. Komor Marcell 1929-ben a Tér és Forma hasábjain megjelent írásában ugyanis a tisztán modern, történeti hagyományoktól teljesen mentes tervezést és tervezésoktatást kérte számon a Mủegyetem professzorain, Hültl Dezsőn és Kotsis Ivánon. ${ }^{86}$ Komor látásmódja, a modern építészeti tervezésen kívül mást meg nem engedő szemlélete és cikkének elvárásokat megfogalmazó hangneme a két világháború közötti építészetelmélet figyelemre méltó kordokumentuma. A történeti építészeti tervezéstől való teljes függetlenedést várt nemcsak a homlokzati formálásban, hanem a tervezés legmélyebb szintjén, a koncepció alkotásában is. Komor cikkére Kotsis Iván a következő lapszámban reflektált. ${ }^{87}$ Az aktuális tanrend ismertetése mellett kifejtette, hogy az építészettörténet és a kortárs tervezés viszonya a 19. századi állapothoz képest megváltozott, de hangsúlyozta, hogy a tervezés „,nem megszüntette, csak megváltoztatta" az építészettörténet oktatásban játszott szerepét. ${ }^{88}$ Míg az építészképzés intézményesülésének hajnalán a tanszékek aszerint tagolódtak, hogy milyen történeti stílusban oktatták a tervezést, addig 1930-ban az új technológia, épületszerkezetek, térigények stb. mentén gyökeresen megváltozott tervezés eszköztárában a történeti formák már nem közvetlenül jelentek meg. Közvetett szerepük fontosságára azonban Kotsis három érvet is felsorolt:

1. a kortárs tervező építész alapvető szakmai műveltsége, amihez a szakma története elengedhetetlenül fontos;

2. a történeti építészet tanulmányozása gondolatteremtő erejü a kortárs tervezés során, mivel a múltbéli építészeti megoldások a jelenkorban is tanulságokkal szolgálnak;

3. a történeti épületek megismerése elősegíti a kortárs tervezéshez szükséges megfelelő arányérzék és esztétikai kultúra elsajátítását. ${ }^{89}$

Később, életrajzi írásában ezekhez egy negyedik érvet is hozzátett:

4. a müemléki vagy történeti épületek helyreállításához szükséges tudásanyag elsajátítása. ${ }^{90}$

Az általános szakmai megosztottság bizonyos kommunikációs félrehallásaira jó példa, hogy a jó építész müveltsége mindkét érvelésben szempont. Komor is úgy vélekedett, hogy „Nem is lehet igazán jó modern épitész más, mint igazán müvelt ember." $" 91$

${ }^{86}$ Komor 1929. 98.

${ }^{87}$ Kotsis 1930a.

${ }^{88}$ Kotsis 1930a. 194.

${ }^{89}$ Kotsis 1930a. 194-195.

${ }^{90}$ Prakfalvi 2010. 182. Kotsis érveinek tekintetében Hajnóczi Gyula memorizmuselmélete a kérdés további rendkívül érdekes rétegeit fejti fel. Hajnóczi 1993. 501.

${ }^{91}$ Kotsis 1930a. 194-195. 
Komor és Kotsis párbeszéde azt is összefoglalta, hogy a két világháború közötti építészet tervezési elveit a müvészi törekvéseken kívül sokkal profánabb gazdasági tényezők is befolyásolták. Ennek az oktatásba leszármazó hatásait 1930-ban Hültl Dezső rektori székfoglaló beszédében értékelte. ${ }^{92}$ A XII. Nemzetközi Építészkongresszus első témájaként frissen megvitatott oktatási reformok kérdésében tulajdonképpen már úgy tudott nyilatkozni, hogy azok vagy már részei voltak az oktatásnak, vagy folyamatban volt bevezetésük. ${ }^{93}$ Mindazonáltal az építészettörténet oktatásban elfoglalt helyét és mennyiségét úgy tünik, már akkor is határozottan lecsökkentették. A történeti építészet presztízsének halványulását az is mutatja, hogy a kongresszus sajtóbeli visszhangja gyakorlatilag nem is említette az építészhallgatók tervezésen kívüli egyéb rajzainak kiállítását, ami pedig a rajztári tablók alapján igen színvonalas lehetett. Hültl ennek ellenére kiállt az építészettörténeti oktatás, sőt tervezés mellett is: „Ma még nem tartunk ott, hogy kialakult, kiforrott stylusról lehetne beszélni és ha nagyobb representatió, vagy egyházi épületről van szó, nem nélkülözhetjük a történelmi stylusok intuitív belevonását a tervezésbe." 94 Talán épp Komor kritikus hangú cikkére reagált, amikor ezt írta: „Müegyetemünk épitészképzése tehát helyes nyomon jár, midőn az épitészet históriai fejlödését alaposan tanitja, az egyes korok architecturáját, annak szellemét és motivumait megismerteti a hallgatósággal, mert ezen az egészséges alapon aztán önállóan alkotni képesek lesznek. Viszont a tervezési gyakorlatoknál nem köti meg a leendö épitömüvészek kezét, hagyja fantáziájukat és izlésüket szabadon kifejlödni... ",95

\section{BIBLIOGRÁFIA}

Bierbauer 1929

Bierbauer 1930

Fábián 1930

Farbaky 1984

Ferkai 1989

Hajdú-Prakfalvi 1995

Hajnóczi 1993
Bierbauer Virgil: A XII. Nemzetközi Építészkongresszus 1930-ban Budapesten. Tér és Forma 2 (1929) 9. (szeptember) 370-372.

Bierbauer Virgil (szerk.): Architectura. XII Nemzetközi Épitészkongresszus és Épitészeti Tervkiállitás. Budapest 1930.

Fábián Gáspár: Nemzetközi építészeti kiállítás a Műcsarnokban. Épitő Ipar Épitö Müvészet 54 (1930) 35-36. (szeptember 15.) 140.

Farbaky Péter: A Fasori Református Templom. Ars Hungarica (1984) 2. 255-269.

Ferkai András: Nemzeti építészet a polgári sajtó tükrében. I. rész, 1920-1930. Épités- Épitészettudomány 20 (1989) 3-4. 331-363.

Hajdú Virág - Prakfalvi Endre (szerk.): Lapis Angularis I. Források a Magyar Épitészeti Múzeum gyüjteményéből. OMvH Magyar Építészeti Múzeum, 1995. Hajnóczi Gyula: Memorizmus. In: Lỏvei Pál (szerk.): Horler Miklós hetvenedik születésnapjára. Tanulmányok. Mủvészettörténet - Mủemlékvédelem IV. OMvH, 1993. 501-505.

\footnotetext{
${ }^{92}$ Hültl 1930b. 165.

${ }^{93}$ Hültl 1930a. 156.

${ }^{94}$ Hültl 1930a. 157.

${ }^{95}$ Uo.
} 
Hültl 1930a

Hült11930b

Kárpáti 1930

Kiss 1930

Komor 1929

Kotsis 1930 a

Kotsis $1930 b$

Kotsis 1930 c

K. Virágh 1929

Lechner 1930

Lending 2014

Magyar 1930a

Magyar 1930b

Magyar 1930. I.

Magyar 1930. II.

Magyar 1930. III.

Magyar 1930. IV.

Magyar 1931. V.

Magyar 1931. VI.

Magyar 1931. VII.
Dr. Hültl Dezső építőművész, Rektor Magnificus székfoglaló beszédéből: „A modern építésznevelésről.” Épitő Ipar - Építő Müvészet 54 (1930) 39-40. (október 15.) 155-157.

Dr. Hültl Dezső építőmüvész, Rektor Magnificus székfoglaló beszédéből: „A modern építésznevelésről.” II. Épitő Ipar - Épitő Müvészet 54 (1930) 4142. (november 1.) 164-165.

Kárpáti Aurél: A magyaros építészeti törekvések kiállítása a Nemzeti Szalonban. Magyar Iparmüvészet 33 (1930) 161-162.

Kiss Dezső: A XII. Nemzetközi Építészkongresszus tárgyalási anyaga. Épitő Ipar - Épitö Müvészet 54 (1930) 7-8. (február 15.) 29.

Komor Marcell: Az építésztanárok hivatásáról. Tér és Forma 2 (1929) 3. (április) 92-98.

Kotsis Iván: Építésznevelés a Müegyetemen. Tér és Forma 3 (1930) 4. (április) 192-195.

Kotsis Iván (szerk.): A budapesti M. Kir. József Műegyetem építészhallgatóinak tervkiállítása 1930. Klny. Technika 11 (1930) 7.

Kotsis Iván: Adatok az építészneveléshez II. Építö Ipar - Épitő Müvészet 54 (1930) 45-46. (december 1.) 181.

K. Virágh Andor: Nemzetközi Építészkongresszus Budapesten címü bejegyzés. A Magyar Mérnök- és Épitész-Egylet Közlönye 63 (1929) 25-26. (június 23.) 157.

Lechner Jenő: Grundriss der Geschichte der ungarischen Baukunst und des Eklektizismus des neuesten Zeitalters. In: Bierbauer Virgil (szerk.): Architectura. XII Nemzetközi Épitészkongresszus és Épitészeti Tervkiállitás. Budapest 1930. 11-24.

Lending, Mari: The Permanent Collection of 1925: Oslo Modernism in Papír and Models. Architectural Histories 2 (2014) 1. Art. 3. DOI: http://doi. org/10.5334/ah.be, https://journal.eahn.org/articles/10.5334/ah.be/ (Utolsó megtekintés: 2018. 09. 06.)

Magyar Vilmos: A XII. Nemzetközi építészkongresszus tervkiállításának mérlege. A Magyar Mérnök- és Építész-Egylet Közlönye 64 (1930) 47-48. 378-381.

Magyar Vilmos: Magyaros építészeti törekvések kiállítása a Nemzeti Szalonban. Magyar Építömüvészet 30 (1930) 9. 15-32.

Magyar Vilmos: XII. Nemzetközi építész-kongresszusról. I. Fritz Höger. Építö Ipar - Építö Müvészet 54 (1930) 37-38. (október 1.) 148-149.

Magyar Vilmos: XII. Nemzetközi építész-kongresszusról. II. Újabb német építőmüvészet. Épitö Ipar - Épitő Müvészet 54 (1930) 39-40. (október 15.) 158.

Magyar Vilmos: XII. Nemzetközi építész-kongresszusról. III. Achitectura. Épitö Ipar - Épitö Müvészet 1930. november 15. 54 (1930) 43-44. (november 15.) $173-175$.

Magyar Vilmos: XII. Nemzetközi építész-kongresszusról. IV. Külföldi államok az építészek nemzetközi tervkiállításán. Építö Ipar - Épitő Müvészet 54 (1930) 47-48. (december 15.) 189-191.

Magyar Vilmos: XII. Nemzetközi építész-kongresszusról. V. Magyarország az építészek nemzetközi tervkiállításán. Építö Ipar - Építö Müvészet 55 (1931) 3-4. (január 15.) 12-14.

Magyar Vilmos: XII. Nemzetközi építész-kongresszusról. VI. Magyar nemzeti és népies építészet. Építö Ipar - Épitő Müvészet 55 (1931) 5-6. (február 1.) 20-22.

Magyar Vilmos: XII. Nemzetközi építész-kongresszusról. VII. Tanulságok, amelyek kritikának is beillenek. Építö Ipar-Épitö Müvészet 55 (1931) 7-8. (február 15.) 29-30. 
Prakfalvi 2010

Rerrich 1930
Prakfalvi Endre (szerk.): Kotsis Iván: Életrajzom. HAP Galéria - Magyar Építészeti Múzeum, 2010.

Rerrich Béla: Nemzetközi Építészkongresszus Budapesten. Épitő Ipar - Épitő Müvészet 54 (1930) 3-4. (január 15.) 9-11.

\title{
Folyóiratközlemények
}

8 órai újság 16 (1930) (szeptember 14.) 3.

Az Est 1929 (november 3.) 9.

Budapesti Hirlap 50 (1930) 174. (augusztus 2.) 5.

Budapesti Hirlap 50 (1930) 201. (szeptember 15.) 4.

Épitö Ipar - Építö Müvészet 54 (1930) 21-22. (június 1.) 87. Krónika rovat

A XII. Nemzetközi Építészkongresszus 1930. szeptember 6-13-ig ideiglenes programja. Épitő Ipar Épitö Müvészet 54 (1930) 29-30. (augusztus 1.) 119-120. Hivatalos rész rovat

Magyar Iparmüvészet 33 (1930) 162. (rövid bejegyzés a műegyetemi kiállításról, szerző: K. I.)

Tér és Forma 3 (1930) 9. (szeptember) 381-420.

Tér és Forma 4 (1931) (július) 7.

Turán. A Turáni Társaság folyóirata 13 (1930) 1-4. 67.

\section{HISTORY OF ARCHITECTURE AND ARCHITECTURAL DESIGN \\ QUESTIONS REGARDING THE REFORMS \\ OF ARCHITECTURAL EDUCATION APROPOS OF THE TECHNICAL UNIVERSITY EXPOSITION OF THE INTERNATIONAL CONGRESS OF ARCHITECTS IN 1930}

\begin{abstract}
Summary
The XII ${ }^{\text {th }}$ International Congress of Architects of 1930 organised in Budapest has been one of the most impressive events of the society of Hungarian architects in the interwar period. Associated with the program of the congress, an international architectural exposition took place in the Hall of Art of Budapest, and an exposition of architectural students' plans was composed in the Technical University. The press coverage of the latter has certainly been dwarfed by the former, however, a coherent series of drawings has been revealed from the Plan Collection and Archives of the Department of History of Architecture and Monument Preservation recently, that, according to their titles in five languages, dates from the period in question and special graphical appearance are likely to have been a part of the exposition of the Technical University. The uniformly mounted drawings of historical architecture are almost the only evidence of the fact that besides design education, the exposition of students also represented drawings from divers subjects, including history of architecture. The series of images provides contributions of high importance about the education of history of architecture in the interwar period, while the press coverage of the congress and the expositions demonstrate the surviving connection between architectural design and history of architecture after their $19^{\text {th }}$-century interference.
\end{abstract}

Keywords: 1930, architectural congress, Technical University, history of architecture

Schlüsselwörter: 1930, Architektenkongress, Technische Universität, Geschichte der Architektur 


\section{MELLÉKLET}

Budapesti Müszaki és Gazdaságtudományi Egyetem, Építészettörténeti és Múemléki Tanszék Rajz és Fotótára, 103242-103263-as jelzetü építészettörténeti rajzokat tartalmazó, egységes formátumú tablósorozat.

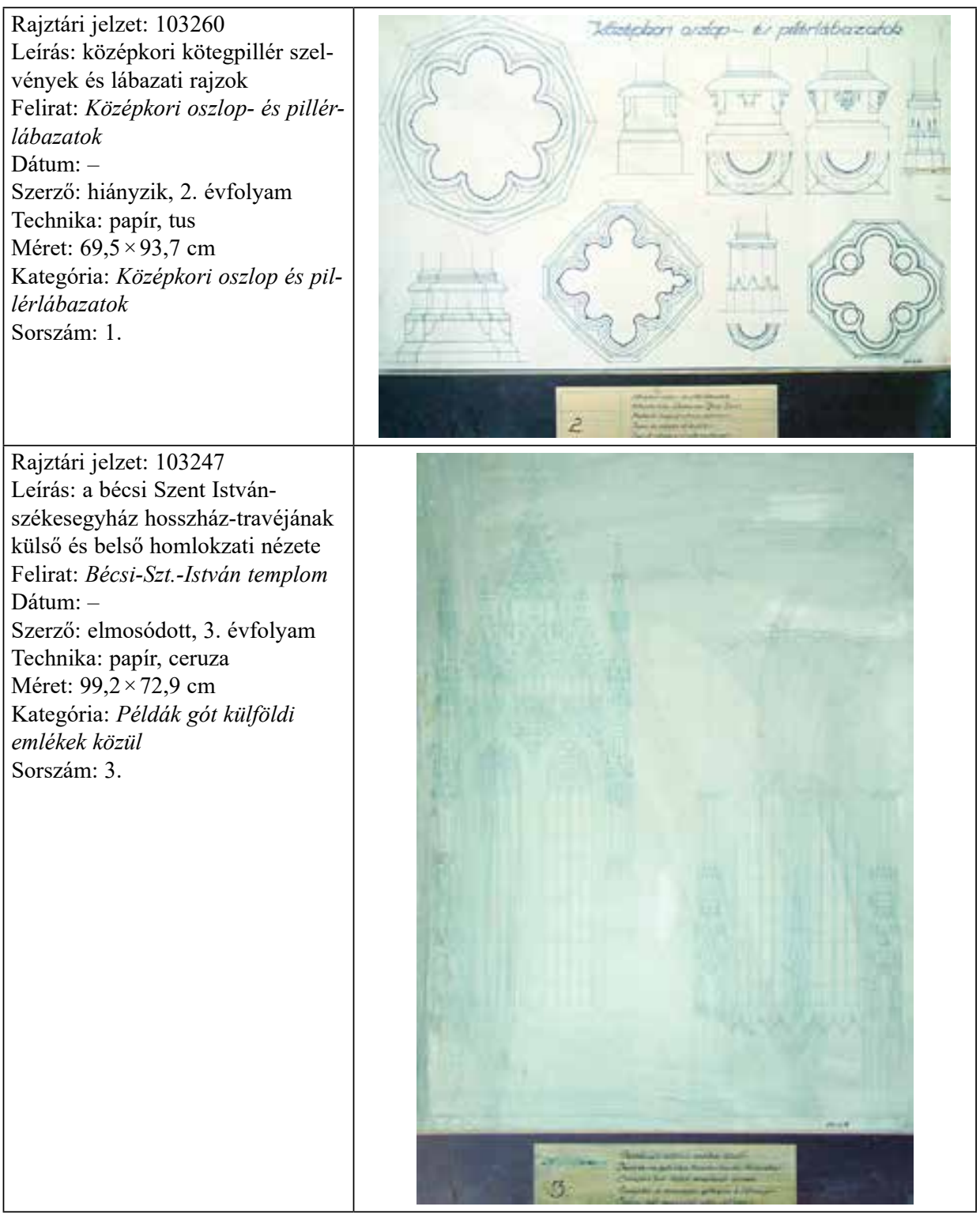




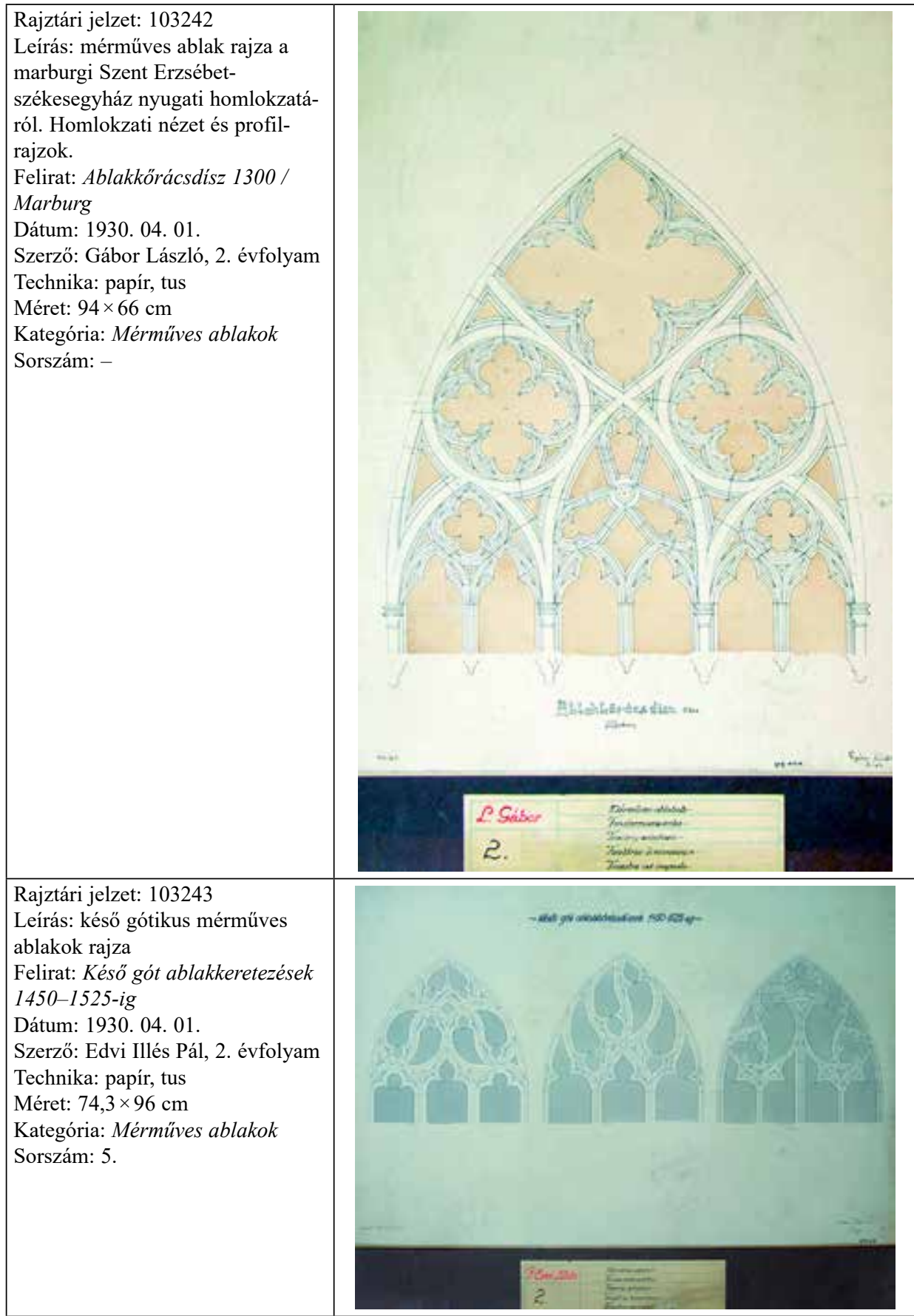




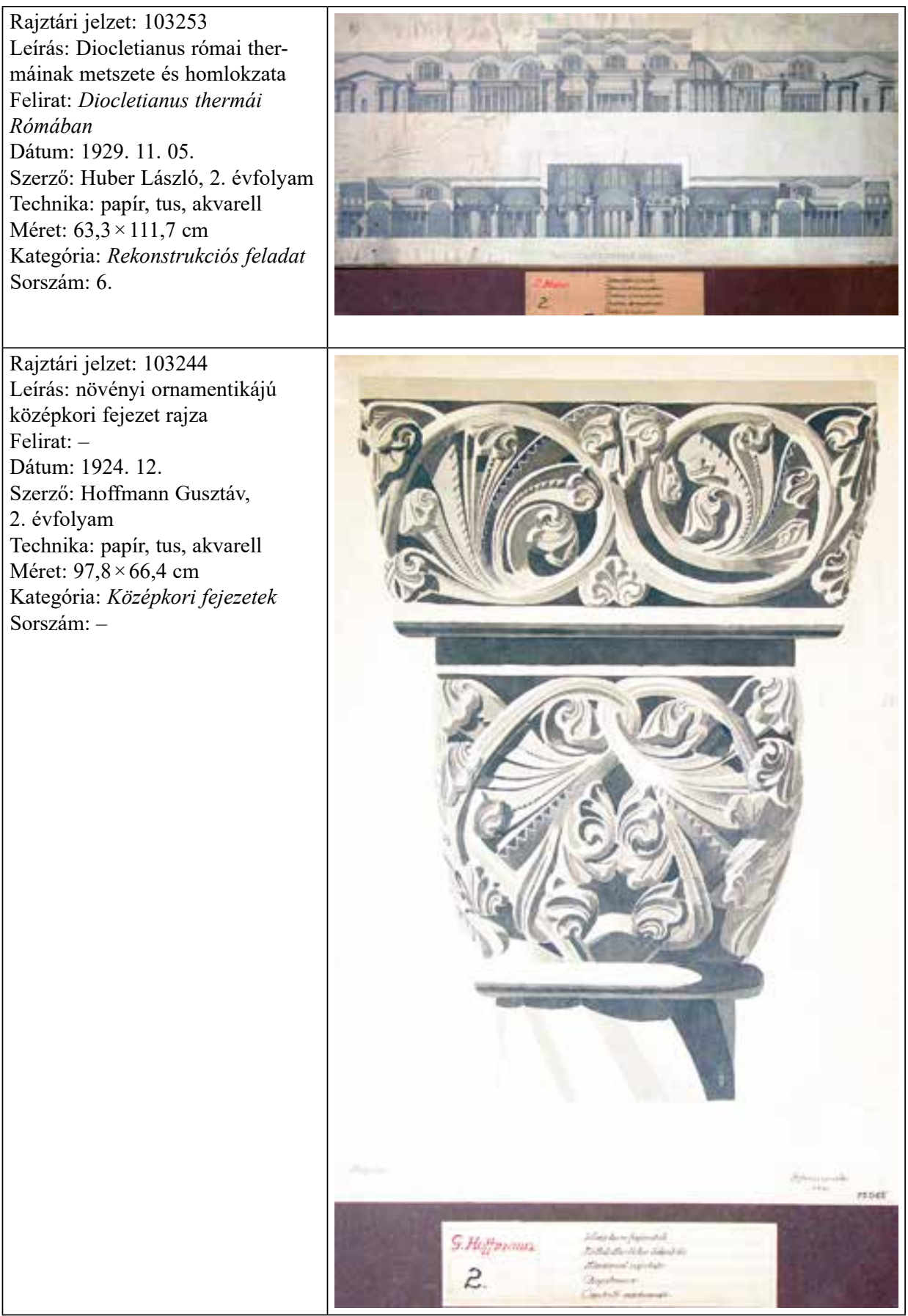




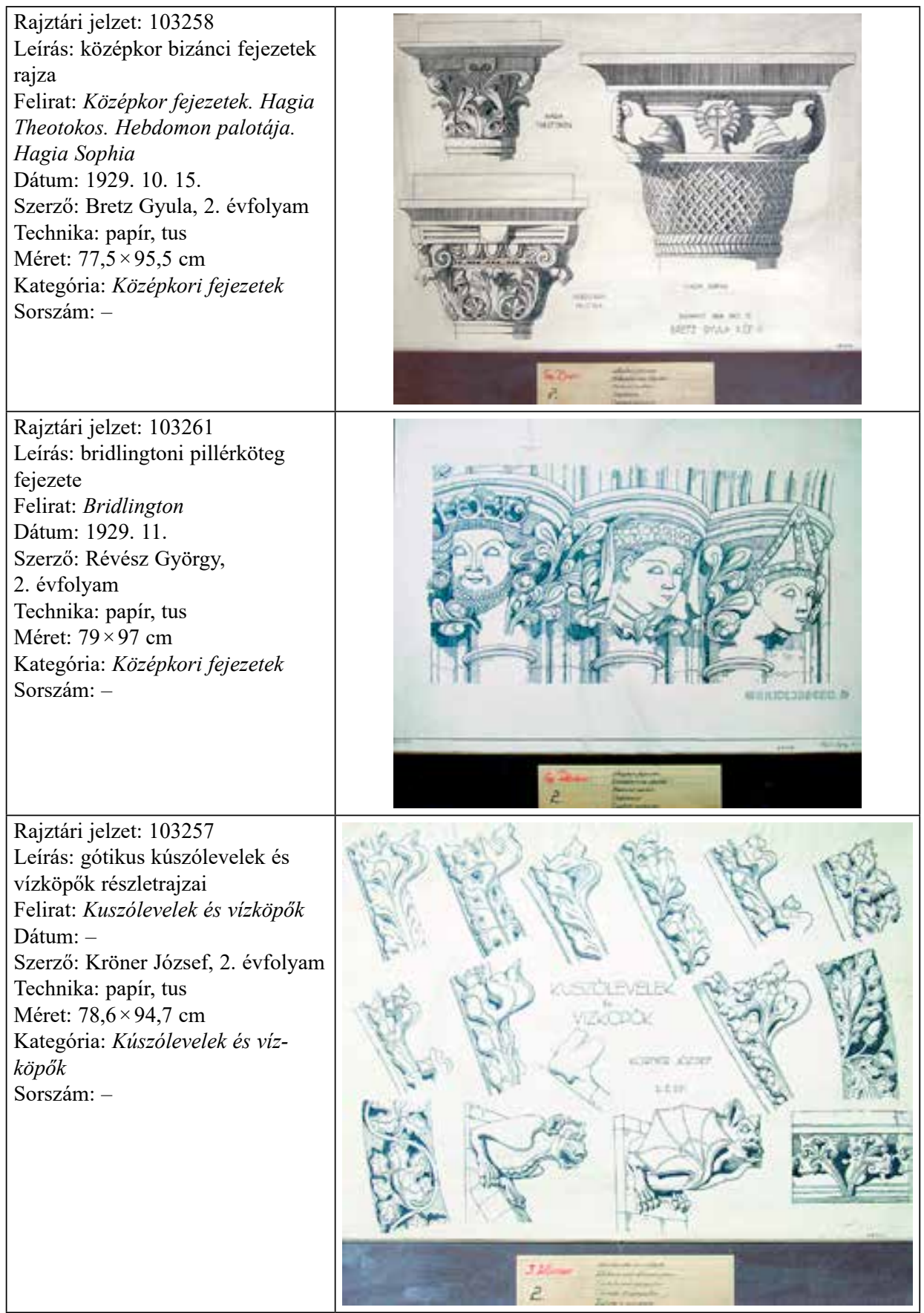




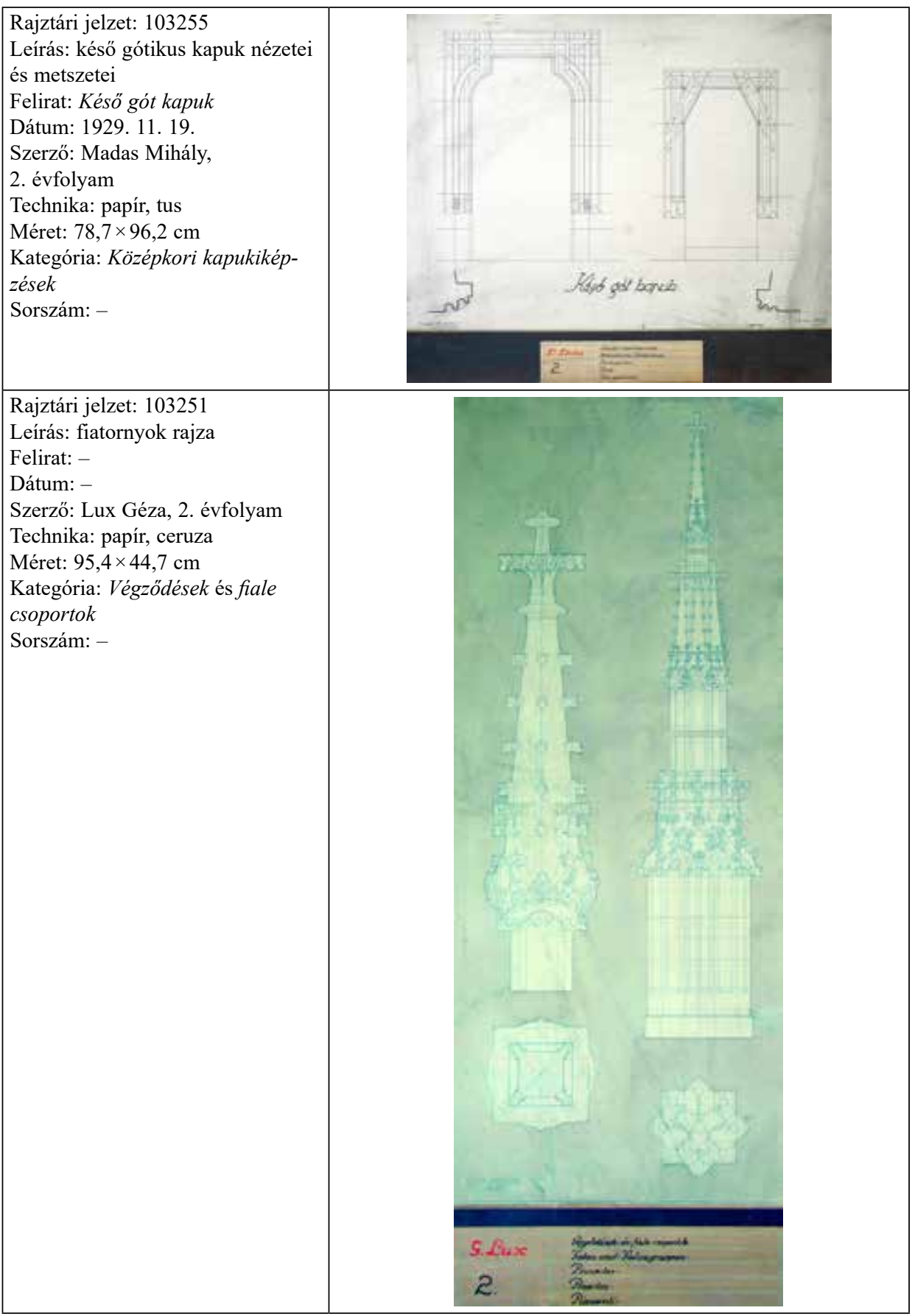




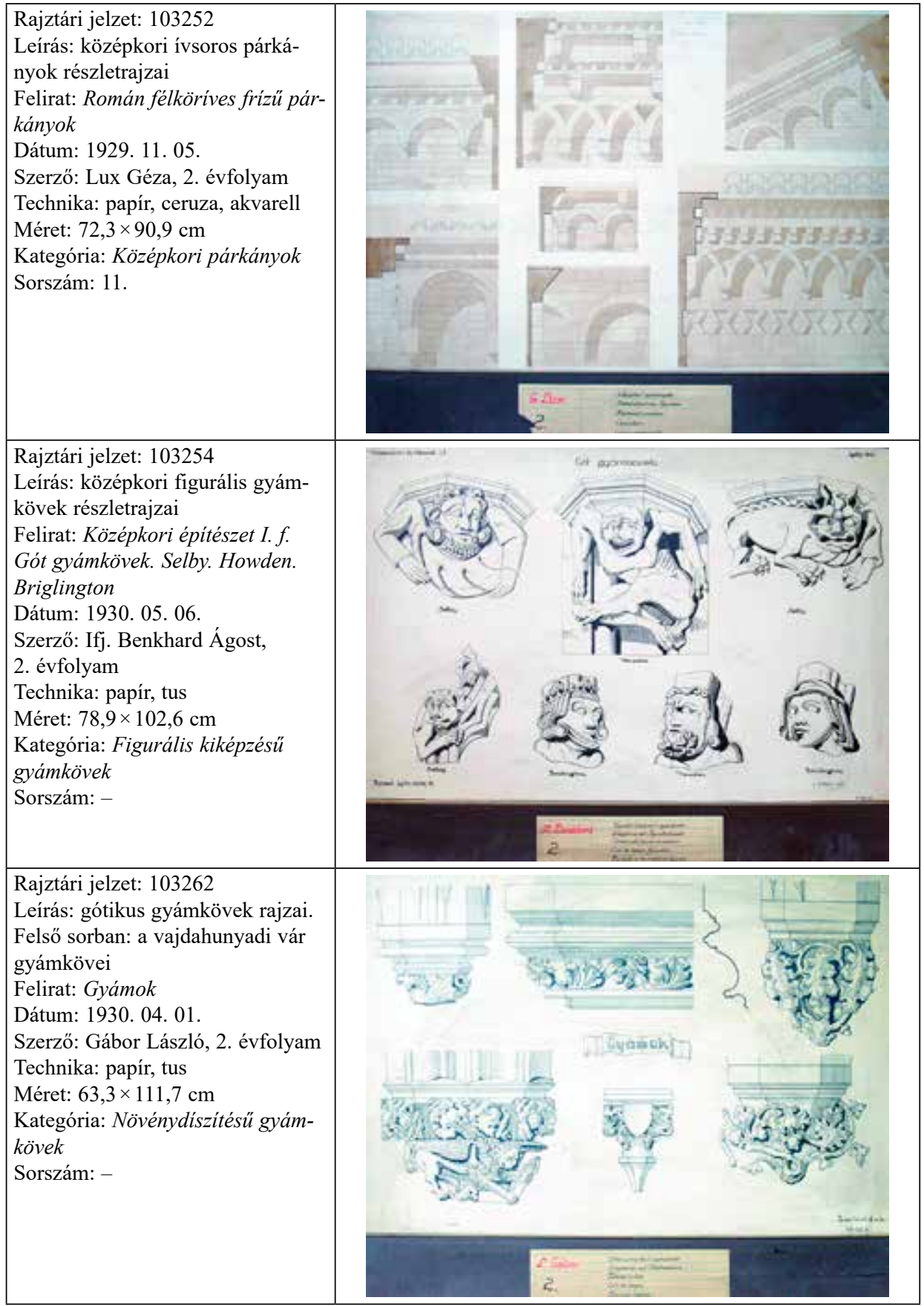




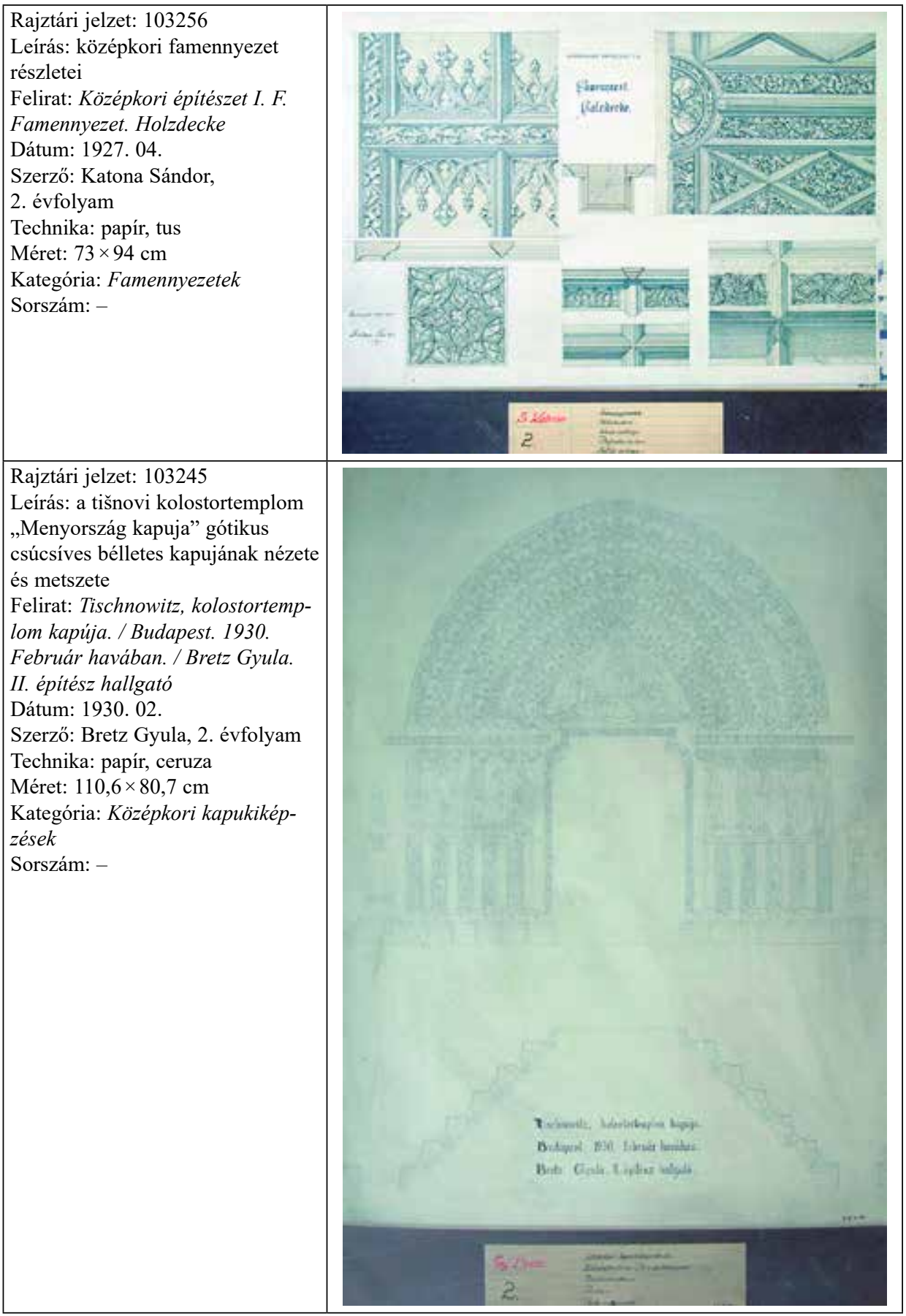




\section{Rajztári jelzet: 103259}

Leírás: a třebíč-i templom rózsaablakának nézete és alaprajza templomból

Dátum: 1927. 05. 16.

Szerző: Gaál Ferenc, 2. évfolyam Technika: papír, tus, akvarell Méret: 93,6×81,5 cm Kategória: Rózsaablak Sorszám: Felirat: Rózsa ablak a Trebitschi

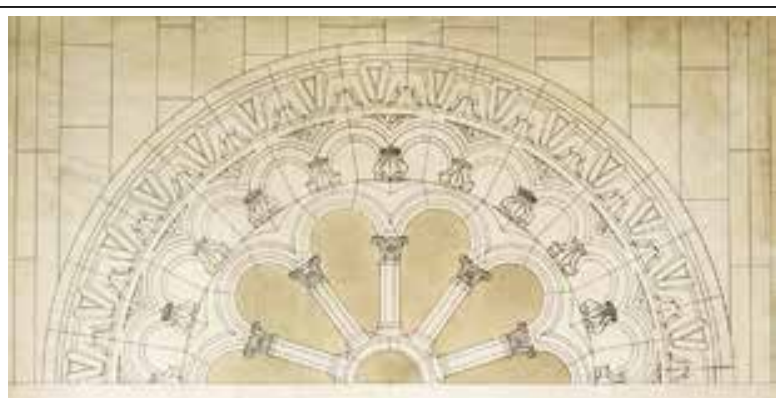

\section{Qússa ublab a trebilsch tomplombol.}
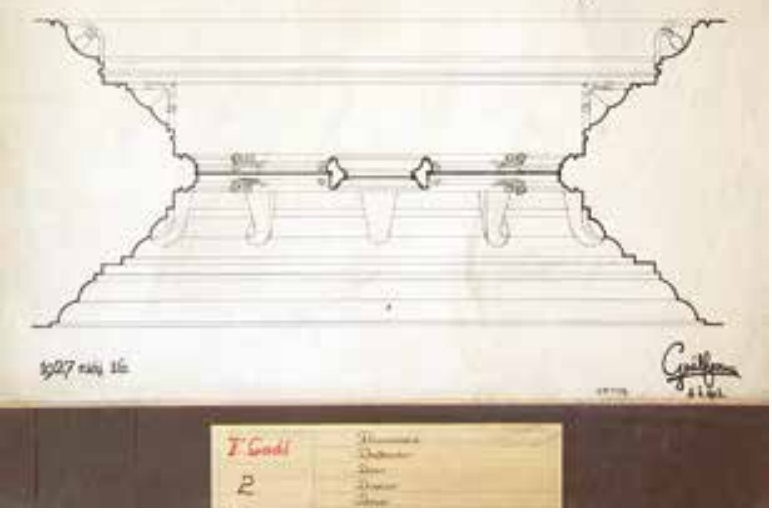

Rajztári jelzet: 103263

Leírás: Keresztvirágok részletrajzai Felirat: Keresztvirágok

Dátum: 1930. 03.

Szerző: Bretz Gyula, 2. évfolyam

Technika: papír, tus

Méret: $75,7 \times 100 \mathrm{~cm}$

Kategória: Keresztvirágok

Sorszám: -

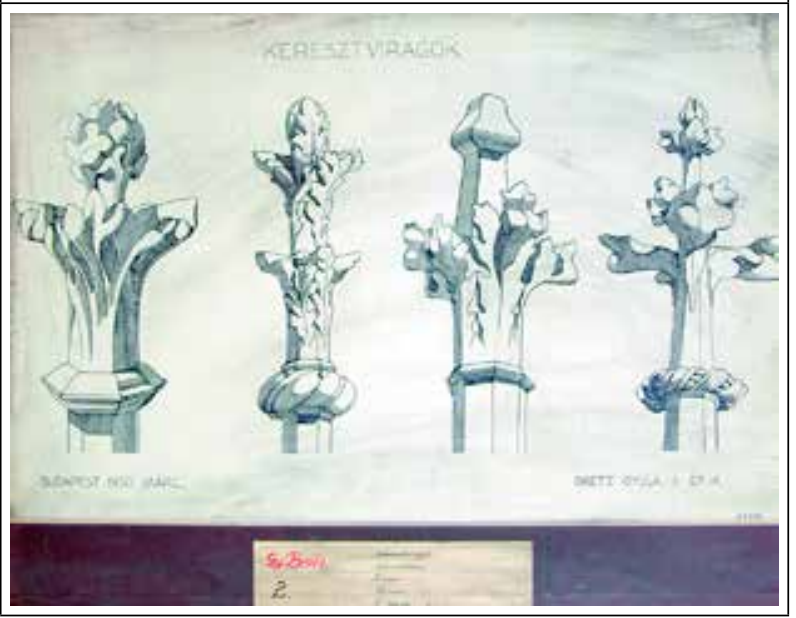




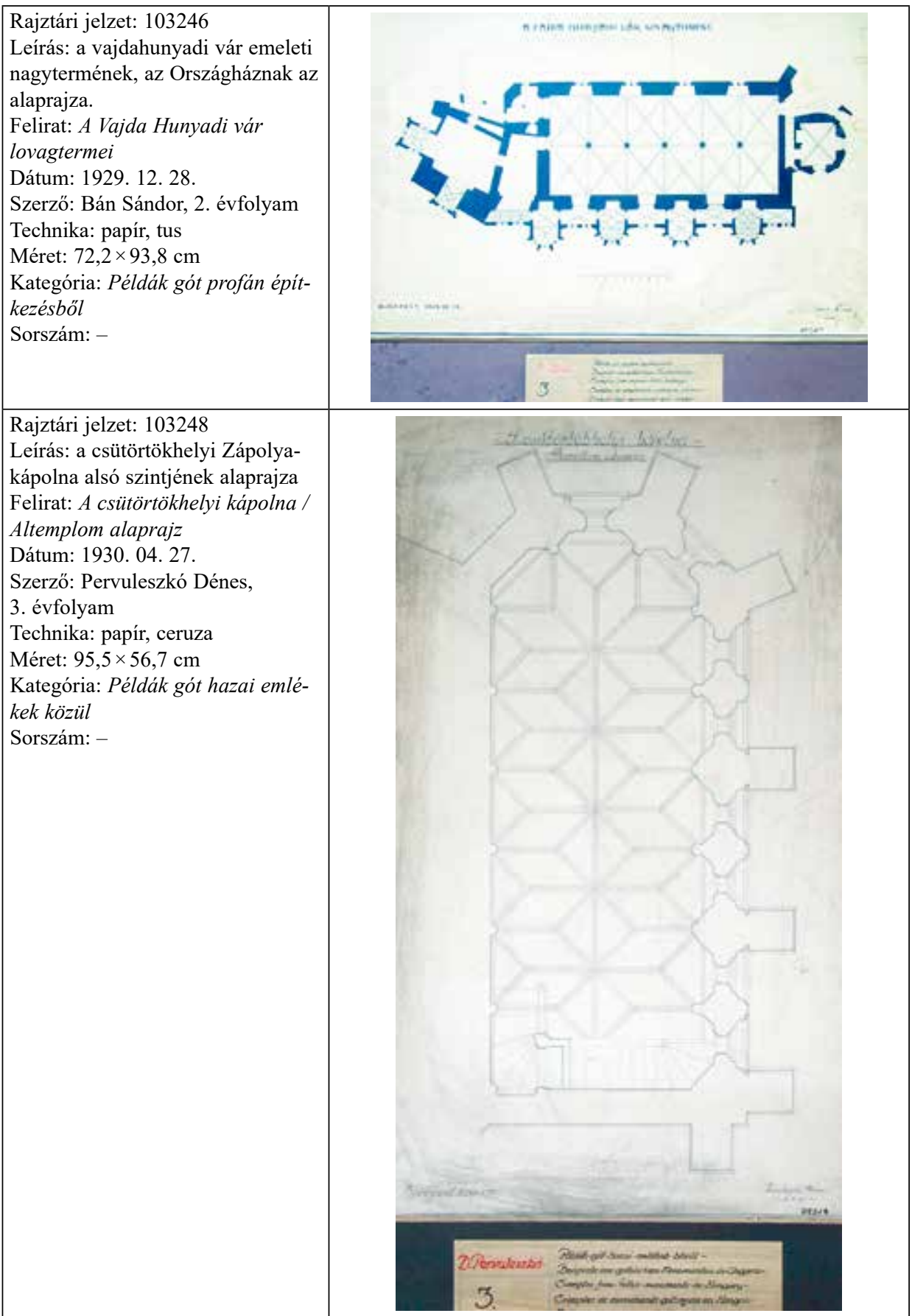




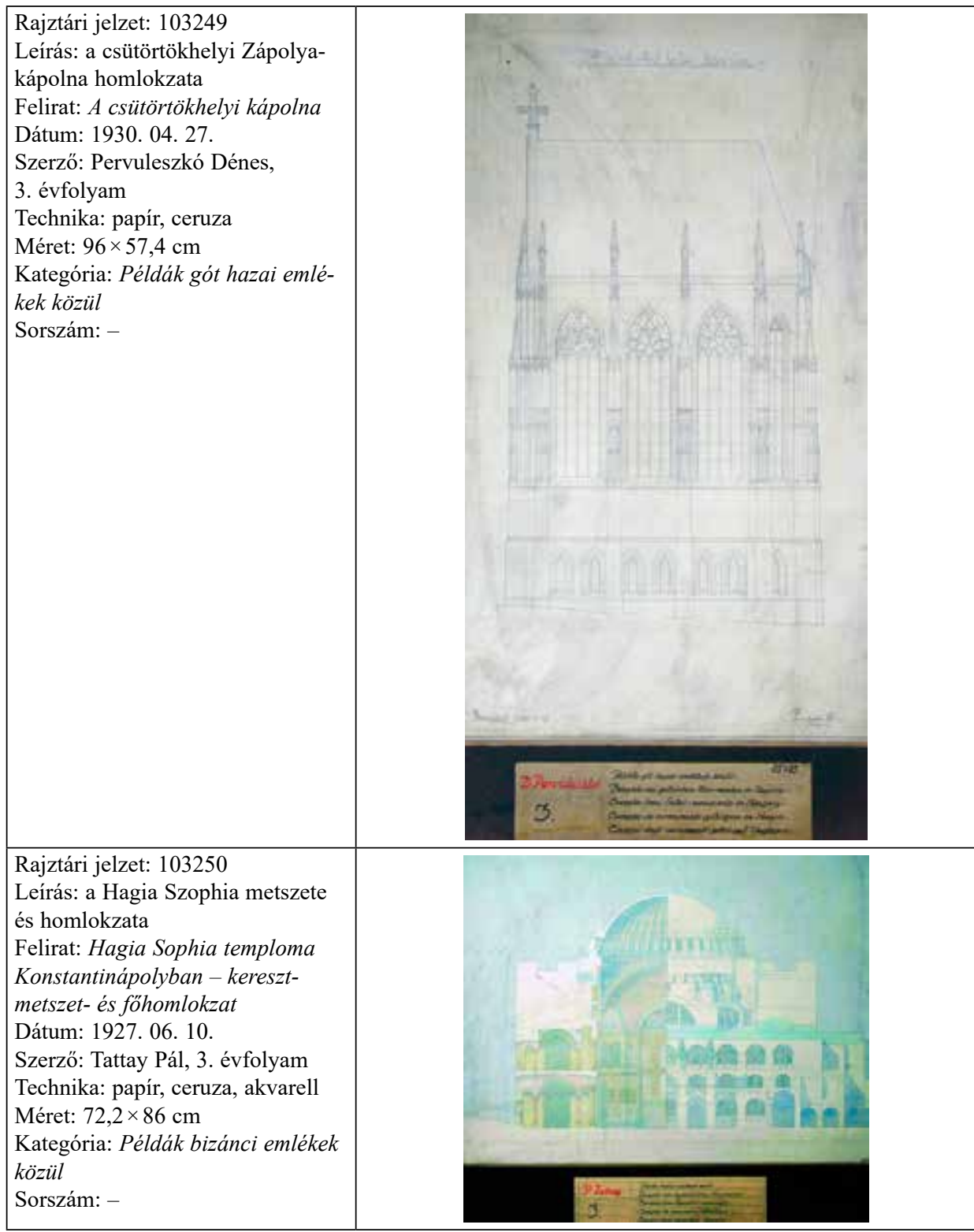

A cikk a CC Attribution 4.0 International License (https://creativecommons.org/licenses/by/4.0) feltételei szerint publikált Open Access közlemény, melynek szellemében a cikk bármilyen médiumban szabadon felhasználható, megosztható és újraközölhető, feltéve, hogy az eredeti szerző és a közlés helye, illetve a CC License linkje és az esetlegesen végrehajtott módosítások feltüntetésre kerülnek.

Beérkezett: 2018. szeptember 18. Elfogadva: 2018. október 23. 
